Zofia Rzeźnicka (Łódź)

\title{
Wine And Myrrh as Medicaments or a Commentary on Some Aspects of Ancient and Byzantine MediterRanean Society
}

\section{Purpose and method}

$\mathrm{T}$ he purpose of this study is to demonstrate the value of medical source texts in researching the history of both pharmacology and ancient societies ${ }^{1}$. The study entails the analysis of a carefully selected extract from the literary output of Pedanius Dioscorides, a luminary in ancient studies of materia medica ${ }^{2}$.

Short though it is, the said passage offers a wealth of information related to both spheres of our research, and as such, it is beyond us to focus on all the elements within the text that could potentially be significant to the result of the deliberations herein. Therefore, while referring to the outcomes of our previous analyses ${ }^{3}$, we made a selection of material, focusing on the two constituents, which - to the best of our knowledge - most effectively illustrate the relationship between medical formulas and the social standing of their recipients.

The first is wine, selected as it is a recurring element in the subject matter within the chosen texts, i.e. the therapeutic alcoholic beverages listed in Book V

\footnotetext{
${ }^{1}$ The text written within the framework of a grant by the National Science Centre, Poland (Miniatura [1] DEC-2017/01/X/HS3/01574) awarded to Zofia Rzeźnicka as well as grands awarded to Maciej Kokoszko (in 2017) and Zofia Rzeźnicka (in 2018) by the De Brzezie Lanckoronski Foundation. ${ }^{2}$ There are seven recipes for therapeutic wines - Pedanii Dioscuridis Anazarbei de materia medica libri V, V, 72, 1, 1 - 3, 9, vol. I-III, ed. M. Wellmann, Berolini 1906-1914 (cetera: Dioscorides, De materia medica).

${ }^{3}$ M. Кокоszко, Enologia Dioskuridesa, czyli kilka uwag na temat leczniczego działania wina, [in:] Historia panaceum. Między marzeniem a oszustwem, ed. W. Korpalska, W. ŚlusarczyK, Bydgoszcz 2016, p. 49-62; Z. Rzeźnicka, Mirra w antycznej medycynie i kosmetyce na podstawie pism Dioskuridesa, [in:] Lek roślinny, vol. VI, Rośliny w lecznictwie, $w$ środowisku naturalnym i $w$ krajobrazie kulturowym, ed. B. PŁonka-Syroka, A. Syroka, Wrocław 2017, p. 53-65.
} 
of De materia medica. We will attempt to present the manner in which the type of wine specified in any given formula indicates the binding rules of constructing recipes in antiquity and what it tells us about the patients themselves.

Secondly, of the substances used to aromatise the potation, we chose myrrh, since it most distinctly indicates the phenomena of interest to us. The other elements that make up Dioscorides' accounts were therefore only analysed to an extent that was, to our mind, significant for the completion of the research objective.

\section{Dioscorides, his work and wine}

The extracts to which we devoted our attention were written by Pedanius Dioscorides. A native of Anazarbus, he was a physician connected, probably for a short while only ${ }^{4}$, with the Roman army ${ }^{5}$ under the reigns of Claudius and Nero. It must, however, be stated that his military career is uncertain, and doubts have been convincingly laid out by John Riddle ${ }^{6}$, and recently recapitulated by Gavin Hardy and Laurence Totelin ${ }^{7}$.

Dioscorides earned his place in history as the author of the treatise De materia medica, which constitutes a collection of information on miscellaneous substances from plants, animals and minerals which were applied in medical practice until the $1^{\text {st }}$ century A.D. The main sources used by Dioscorides were the works by Crateuas $\left(1^{\text {st }} \text { century B.C. }\right)^{8}$, Andreas $\left(3^{\text {rd }} \text { century B.C. }\right)^{9}$, Julius Bassus $\left(1^{\text {st }} \text { century A.D. }\right)^{10}$, Niceratus $\left(1^{\text {st }} \text { century A.D. }\right)^{11}$, Petronius $\left(1^{\text {st }} \text { century A.D. }\right)^{12}$, Diodotus $\left(1^{\text {st }}\right.$ centu-

\footnotetext{
${ }^{4}$ J. Scarborough, V. Nutton, The Preface of Dioscorides' Materia Medica: Introduction, Translation, and Commentary, TSCPP 4, 1982, p. 213-217; V. NutTon, Ancient Medicine, London-New York 2004, p. 175; J. Scarborough, Dioskouridès of Anazarbos (ca 40-80 CE), [in:] The Encyclopedia of Ancient Natural Scientists. The Greek Tradition and its Many Heirs, ed. P. Keyser, G.L. IrbyMassie, Milton Park-New York 2008, p. 271; M. Koкoszko, K. Jagusiak, Z. Rzeźnicka, J. DybAŁA, Pedanius Dioscorides' Remarks on Milk Properties, Quality and Processing Technology, JAS.R 19, 2018, p. 982.

${ }^{5}$ Cf. M. Wellmann, Dioskurides 12, [in:] RE, vol. V, Stuttgart 1905, col. 1131.

${ }^{6}$ J.M. Riddle, Dioscorides on Pharmacy and Medicine, Austin 1985, p. 2-4.

${ }^{7}$ G. Hardy, L. Totelin, Ancient Botany, London-New York 2016, p. 15.

${ }^{8}$ On the author, cf. J.-M. JACQUes, Krateuas (100-60 BCE), [in:] The Encyclopedia..., p. 491; G. SQuILLACE, I balsami di Afrodite. Medici, malattie e farmaci nel mondo antico, Sansepolcro 2015, p. 64; IDEM, Le lacrime di Mirra. Miti e luoghi dei profumi nel mondo antico, Bologna 2015, p. 15; M.E. IRwIN, Greek and Roman Botany, [in:] A Companion to Science, Technology, and Medicine in Ancient Greece and Rome, vol. I-II, ed. G.L. Irby, Malden-Oxford-Chichester 2016, p. 271-272.

${ }^{9}$ On the author, cf. G.L. Irby-Massie, P.T. Keyser, Greek Science of the Hellenistic Era. A Sourcebook, London-New York 2002, p. 302-303; G.L. Irby-Massie, Andreas of Karustos (ca 250-217 BCE), [in:] The Encyclopedia..., p. 77-78.

${ }^{10}$ On the author, cf. J. Scarborough, Iulius Bassus (ca 10-40 CE), [in:] The Encyclopedia..., p. 451.

${ }^{11}$ On the author, cf. IDEM, Nikeratos (of Athens?) (10-40 CE), [in:] The Encyclopedia..., p. 575-576.

${ }^{12}$ On the author, cf. IDEM, Petrōnios Musa (ca 10-40 CE), [in:] The Encyclopedia..., p. 639.
} 
ry A.D. $)^{13}$ and Sextius Niger ${ }^{14}$ (whose work, importantly for the further narrative, was also used by Pliny the Elder in Naturalis historia). They were complemented with the knowledge and experience that Dioscorides gained while travelling across various countries within the borders of the Roman Empire ${ }^{15}$.

Due to the author's profound competence, the readability of the textual structure, and the simplicity of its language, the treatise proved to be a perfect guidebook to the world of medicaments, and thus it was commonly known to theoreticians and practitioners of medicine, who would frequently quote it, while the assumptions of knowledge promoted by Dioscorides influenced the beliefs and opinions of subsequent generations of physicians ${ }^{16}$.

The inquiries regarding the sources of Dioscorides' competence in wine are based on very uncertain foundations, since the author never refers directly to experts in the field of oenology $y^{17}$, and yet it is beyond any doubt that he used works of others.

Specifically, there is every likelihood that a substantial part of his competence he owed to the information contained in the treatise Perí hýles (Пвpì ü $\lambda \eta \varsigma)$ ), which was compiled (in Greek, not in Latin) by Sextius Niger ${ }^{18}$. A disciple of

\footnotetext{
${ }^{13}$ On the author, cf. IDEM, Diodotos (Pharm.) (10-30 CE), [in:] The Encyclopedia..., p. 250-251.

${ }^{14}$ Dioscorides, De materia medica, I, proemium, 1, 9 - 2, 5. On Sextius Niger, cf. the further part of this article.

${ }^{15}$ Dioscorides, De materia medica, I, proemium, 4, 1 - 6, 2. Cf. M.E. Irwin, Greek..., p. 273.

${ }^{16}$ Cf. M. Wellmann, Dioskurides 12..., col. 1131-1142; J.M. Riddle, Dioscorides..., passim; K. ГЕ-

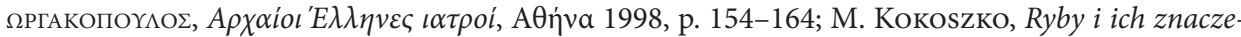
nie w życiu codziennym ludzi późnego antyku i Bizancjum (IV-VII w.), Łódź 2005 [= BL, 9], p. 12; M. Stamatu, Dioskurides, [in:] Antike medizin. Ein Lexikon, ed. K.-H. Leven, München 2005, col. 227-229; V. Nutton, Ancient..., p. 174-177; J. Scarborough, Dioskouridēs of Anazarbos..., p. 271-272; R.A. GABRIEL, Man and Wound in the Ancient World. A History of Military Medicine from Sumer to the Fall of Constantinople, Washington 2012, p. 174-175; G. SQUILLACE, I balsami..., p. 62; M.E. Irwin, Greek..., p. 272-274. On the impact of Greek medical accomplishments, cf. H.D. FrASER, The Influence of Greece on Science and Medicine, ScM 3, 1916, p. 51-65; J. MoravcsiK, Ancient and Modern Conceptions of Health and Medicine, JMP 1, 1976, p. 337-348.

${ }^{17}$ Neither does he refer to his own experience of using the alcoholic beverages discussed herein.

${ }^{18}$ The most comprehensive reflections on the author's output, cf. M. Wellman, Sextius Niger, eine Quellenuntersuchung zu Dioscorides, H 24, 1889, p. 530-569; K. DeICHGRÄBER, Sextius Niger, [in:] RE, Supplementband V, Stuttgart 1931, col. 971-972; N. Everetr, The Alphabet of Galen. Pharmacy from Antiquity to the Middle Ages. A Critical Edition of the Latin Text with English Translation and Commentary, Toronto 2012, p. 70-74. On Sextius Niger and the reception of his works, cf. P. PRIORESCHI, A History of Medicine, vol. III, Roman Medicine, Omaha 1998, p. 280-282; V. Nutton, Ancient...., p. 175, 177, 190; R. Flemming, Galen's Imperial Order of Knowledge, [in:] Ordering Knowledge in the Roman Empire, ed. J. König, T. Whitmarsh, Cambridge 2007, p. 254-255; A. Pietrobelli, The

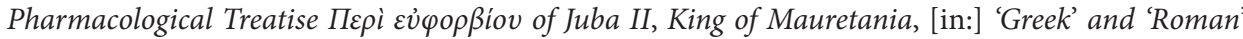
in Latin Medical Texts. Studies in Cultural Change and Exchange in Ancient Medicine, ed. B. MAIrE, Leiden-Boston 2014, p. 176-177; G. Squillace, I balsami..., p. 64; G. Hardy, L. Totelin, Ancient..., p. 50-51; M.E. Irwin, Greek..., p. 274, 276; M. Jones-Lewis, Pharmacy, [in:] A Companion..., p. 406.
} 
Asclepiades of Bithynia ${ }^{19}\left(2^{\text {nd }} / 1^{\text {st }}\right.$ centuries B.C. $)$, he was professionally active between the second half of the $2^{\text {nd }}$ century B.C. and the first half of the $1^{\text {st }}$ century A.D. Even though Dioscorides did not value all aspects of Niger's achievements and output, he did recognise his significance as an expert in the realm of materia medica $^{20}$, and - beyond any doubt - utilised his treatise to a wide extent. We know this because his critical remarks reveal that he was well aware of mistakes made by Sextius ${ }^{21}$, and yet still appreciated the informative value of this work.

Although the exact extent of Dioscorides' borrowings from Perí hýles is unknown, there are at least several premises regarding the meaning of the data collected by Niger for the section of De materia medica devoted to wine.

First and foremost, analogical and - at times - even identical information can be found in Naturalis historia by Pliny the Elder, who openly admitted to quoting data directly from the treatise of his Roman predecessor, in the sections devoted to wine ${ }^{22}$.

Secondly, Dioscorides and Pliny kept an analogical composition of data, which had evidently been derived from Perí hýles, divided geographically into Italic and non-Italic wines. This division also implies the time at which the source was compiled, so not only the period in which Italia was already an important and recognised winemaking centre, producing highly valued brands of wine, but also the time when they were already acknowledged as suitable for medical application (just like the alcoholic beverages from the eastern regions of the Mediterranean Sea that had been known for centuries).

It follows from this conclusion that the author of the source text to which Dioscorides and Pliny referred must have compiled his work when medicine had already blossomed in Italia, and Romans had begun to recognise its effectiveness and started practising it themselves. Therefore, the work must have been written at a time close to Celsus' De medicina ${ }^{23}$, i.e. still in the $1^{\text {st }}$ century B.C., or at the very beginning of the $1^{\text {st }}$ century A.D. This was a crucial period for the development of Roman medicine, since the territory remained under the strong influence of Asclepiades of Bithynia and his disciples, which shaped the Roman ars medica. Therefore, we remain of the opinion that not only did the author

\footnotetext{
${ }^{19}$ On the author, cf. J. Scarborough, Asklēpiadès of Bithunia (in Rome, ca 120-90 BCE), [in:] The Encyclopedia..., p. 170-171; J. RoccA, Anatomy and Physiology, [in:] A Companion..., p. 353-354.

${ }^{20} \mathrm{He}$ directly writes about it in the introduction, cf. Dioscorides, De materia medica, I, proemium, $3,1-2$.

${ }^{21}$ Dioscorides, De materia medica, I, proemium, 3, 1-11.

${ }^{22}$ Pliny writes about wine in Book XIV, and Sextius' work is listed among the database sources used to compile it - C. Plini Secundi naturalis historiae libri XXXVII, I, 14 b, 13, vol. I-VI, ed. C. MAYHoff, Lipsiae 1875-1906 (cetera: Pliny, Naturalis historia). On Pliny and his encyclopaedia, cf. M. BEAgon, Roman Nature. The Thought of Pliny the Elder, Oxford 1992, p. 1-25; EADEM, The Elder Pliny on the Human Animal. Natural History, Book 7, Oxford 2005, p. 1-57.

${ }^{23}$ On the author, cf. F. Sток, A. Cornelius Celsus (15-35 CE), [in:] The Encyclopedia..., p. 217-219.
} 
belong to the Roman cultural and economic circle, but also he was a Roman himself. Even if it is beyond us to prove that he was a physician, the content of the deliberations preserved by Pliny and Dioscorides indicates that the author took a definite interest in the data included in studies written by ancient doctors. The fact that Dioscorides and Pliny decide to present Italic wines first reinforces our firm belief that the author neither came from Greece nor settled permanently in Alexandria ${ }^{24}$, but was connected with Italia and treated Italic products as materia medica. Thus, there is a probability that he was Roman, yet chose to write his work in Greek, i.e. in the language of Mediterranean medicine.

Thirdly, detailed data indicates that Niger was a source of Dioscorides' competence in wine and winemaking, as illustrated by the following examples. Pliny includes a recipe for an alcoholic drink called adynamon ${ }^{25}$, which can also be found in Dioscorides' De materia medica, under the name of adýnamos (ả $\delta \dot{v} v \alpha \mu \varsigma)^{26}$. The text of both formulas is analogical, although Pliny's turns out to be more accurate when it comes to the measures of individual ingredients within the described beverage, thus indicating that Niger had used units of measure in the recipes for the medicaments he described.

Furthermore, in Book XIV ${ }^{27}$ and then XXII of Naturalis historia ${ }^{28}$ (Niger was also listed among the experts ${ }^{29}$ ), we can find an analysis of a wine called melitites in Latin, which corresponds with Dioscorides' reflections in Book V of De materia medica on melitites $\left(\mu \varepsilon \lambda ı \lambda_{i \tau \eta}\right)^{30}$. Significantly, both authors convey the same content, which is similar not only as far as the formula is concerned, but also in terms of the therapeutic applications of the beverage and the vocabulary they use.

It is worth adding one more suggestion here. Namely, there is a distinct possibility that the initial structure of the catalogue of Italic wines, authored by Sextius Niger, is most accurately reflected by a list contained within the Deipnosophistae by Athenaeus of Naucratis $\left(2^{\text {nd }} / 3^{\text {rd }} \text { century A.D. }\right)^{31}$, since the source used by this

\footnotetext{
${ }^{24}$ Then, he would have more likely focused exclusively on traditional alcoholic beverages made by the Hellenes or wines produced in Africa.

${ }^{25}$ Pliny, Naturalis historia, XIV, 100, 1-5. For our deliberations, it is significant that Pliny listed Niger's work within the index of sources for Book XIV, cf. PLINY, Naturalis historia, I, 14b, 13.

${ }^{26}$ Dioscorides, De materia medica, V, 6, 16, 5 - 17, 4.

${ }^{27}$ PLINY, Naturalis historia, XIV, 85, 1-3.

${ }^{28}$ PLINY, Naturalis historia, XXII, 115, 1-6.

${ }^{29}$ The authors native to Ancient Rome used in Book XX were the same writers Pliny read to compile Book XXI. And in the index of names for Book XXI, he also listed Sextius Niger - PlinY, Naturalis historia, I, 21b, 7.

${ }^{30}$ Dioscorides, De materia medica, V, 7, 1, $1-2,7$.

${ }^{31}$ Athenaei Naucratitae dipnosophistarum libri XV, I, 26c - 27d (48, 1-61 KAIBEL), vol. I-III, rec. G. Kaibel, Lipsiae-Berolini 1887-1890 (cetera: Athenaeus of Naucratis, Deipnosophistae). On the author, cf. B. BALDwin, Athenaeus and His Work, AClas 19, 1976, p. 21-42. On wine in the Deipnosophistae, cf. K. BARTol, Atenajosa $z$ Naukratis ksiega win (Deipnosophistai 25f-40f), M 50,
} 
author offered terminology whose provenance was medical, and which focused on alcoholic beverages not from the perspective of the common consumer, but a physician $^{32}$.

Thus, we may venture to elaborate even further. There are premises that Athenaeus of Naucratis also used the remaining part of the wine catalogue compiled by Sextius Niger, and that it was preserved in Book I of the Deipnosophistae ${ }^{33}$. Dioscorides shortened it to the minimum, and yet its traces survived in De materia medica ${ }^{34}$. Plausibly, they were preceded by a passage on the classification of wine $^{35}$, as is suggested by the exact similarity of the data provided by Athenaeus of Naucratis and the information preserved by Dioscorides ${ }^{36}$.

Another important fact is that Pliny and Dioscorides list types of Italic wines in the same order as the author of the Deipnosophistae. Our belief is further reinforced by the premise that Athenaeus of Naucratis and Pliny provide information regarding the period of wine ageing, which includes particularly specific data on the necessity to mature the Falerinos $(\Phi \alpha \lambda \varepsilon \rho \tilde{v} v o \varsigma)^{37}$ wine for fifteen years, which allows us to presume that both authors derived their information from the same source treatise.

Having indicated how likely it is that Dioscorides depended on Sextius Niger as far as the issue of his competence in alcoholic drinks was concerned, it is worth adding that the influence of the latter on the development of ancient people's knowledge within the discussed field was by no means limited to the literary output of Dioscorides and Pliny. Galen of Pergamon $\left(2^{\text {nd }} / 3^{\text {rd }} \text { centuries A.D. }\right)^{38}-$ the most prominent expert and practitioner of ancient medicine - was another scholar

1995, p. 215-226; R. Brock, H. Wirtejs, Athenaeus on Greek Wine, [in:] Athenaeus and His World. Reading Greek Culture in the Roman Empire, ed. D. Braund, J. WiLkins, Exeter 2000, p. 455-465.

${ }^{32}$ As proved by the very first description included within the said catalogue, which lists exactly the same properties that can be found in Galen's output, for instance. Cf. Athenaeus of Naucratis,

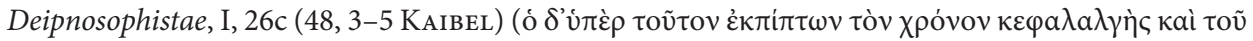

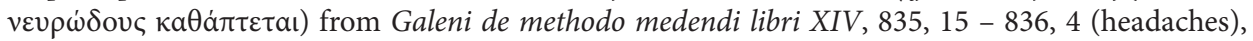
[in:] Claudii Galeni opera omnia, vol. X, ed. C.G. KüHN, Lipsiae 1825 (cetera: Galen, De methodo medendi) and Galeni de rebus boni malique suci libellus, 804, 4-6, (headaches; weakening of hard tissues), [in:] Claudii Galeni opera omnia, vol. VI, ed. C.G. KüHn, Lipsiae 1823 (cetera: Galen, De rebus boni malique suci).

${ }^{33}$ Cf. Athenaeus of Naucratis, Deipnosophistae, I, 32d - 33f (59, 14 - 60, 33 Kaibel).

${ }^{34}$ Dioscorides, De materia medica, V, 6, 11, 9 - 12, 1.

${ }^{35}$ Athenaeus of Naucratis, Deipnosophistae, I, 32c-d (59, 1-8 Kaibel).

${ }^{36}$ Cf. Dioscorides' classification of the taste and colour of wine, to which we refer in the further part of this article.

${ }^{37}$ Pliny, Naturalis historia, XXIII, 35, 1; Athenaeus of Naucratis, Deipnosophistae, I, 26c (48, 3 KAIBEL).

${ }^{38}$ On the author and his output, cf. R. Flemming, Galen's..., p. 241-277; S.P. Mattern, The Prince of Medicine. Galen in the Roman Empire, Oxford 2013, passim. 
who expressly admitted to knowing the treatise Perí hýles ${ }^{39}$, and he thus may have used its data on wine, as is evidenced by a similar range of terms that he shared with Dioscorides, Pliny and Athenaeus of Naucratis, the same division into Italic and non-Italic wines, and the order in which he described individual types of beverages within both classes ${ }^{40}$.

Galen devoted a substantial amount of his attention to wine ${ }^{41}$. The starting point of his deliberations was his reflections in De diaeta in morbis acutis, which

${ }^{39}$ Galeni de simplicium medicamentorum temperamentis ac facultatibus libri XI, 797, 6, vol. XI, [in:] Claudii Galeni opera omnia, vol. XI-XII, ed. C.G. KüHN, Lipsiae 1826-1827 (cetera: GaLEN, De simplicium medicamentorum temperamentis ac facultatibus); Galeni de antodotis libri II, 7, 2, [in:] Claudi Galeni opera omnia, vol. XIV, ed. C.G. KüHN, Lipsiae 1827; Galeni de linguarum seu dictionum exoletarum Hippoctratis explicatio, 64, 10, [in:] Claudi Galeni opera omnia, ed. C.G. KüHN, vol. XIX, Lipsiae 1830.

${ }^{40}$ To prove this thesis, one only needs to recapitulate the details regarding the catalogues of Italic wines. Dioscorides lists them in the following order: Falerínos (V, 6, 6, 1-2), then Albanós ('A $\lambda \beta a-$

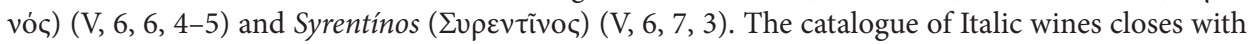

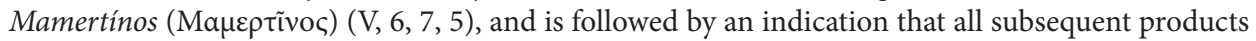
are non-Italic, and more precisely, wines from Sicily ( $\gamma \varepsilon v v \omega \dot{\omega} \mu \varepsilon v o \varsigma$ $\left.\delta \dot{\varepsilon} \dot{\varepsilon} v \sum ı \kappa \varepsilon \lambda \dot{i a q}[\mathrm{~V}, 6,7,6-7]\right)$. This

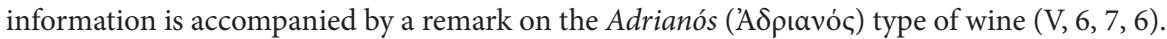

Meanwhile, Pliny preserves the following sequence: Falernum (XIV, 62, 1), Albanum (XIV, 64, 1) and Surrentinum (XIV, 64, 2), which is preceded by an explanation that the Caecubum wine was no longer produced (XIV, 61, 4-8). Customarily, Mamertinum closes the catalogue of wines, and is followed by a notion that the author moves on to Sicilian wines (Mamertina circa Messanam in Sicilia genita [XIV, 66, 3]), and the passage is supplemented with information on wines from the regions of the Adriatic Sea (XIV, 67, 1-2).

We presume that Galen may also have used the works by Sextius Niger, since he preserved the information of the three top-quality types of Italic wine. For instance, in De sanitate tuenda, they were listed in an extract devoted to wines which possessed an appelation d'origine, cf. Galeni de sanitate tuenda libri VI, 334, 6 - 335, 8, [in:] Claudii Galeni opera omnia, vol. VI, ed. C.G. KüHN, Lipsiae 1823 (cetera: GALEN, De sanitate tuenda). Falerínos was mentioned first and followed directly

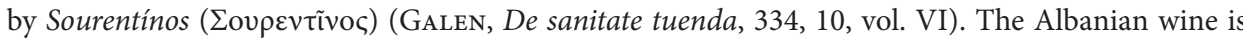
placed after the liquor from Sorrento (GALEN, De sanitate tuenda, 335, 1, vol. VI), since it was classified as one of the Aminaean wines, and thus grouped among other brands produced from the same variety of grape (GALEN, De sanitate tuenda, 335, 1-2, vol. VI).

The last of the quoted authors, Athenaeus, begins with the Falernian wine (I, 26c [48, 2 KAIBEL]), and then lists the Albanian beverage (I, 26d [48, 9 KAIBEL]), and closes the list with Syretinos (I, 26d [48, 11-12 KAIBEL]). The paragraph on Italic wines closes with a remark on Mamertínos (I, 27c [48, 59 KaIBEL]), with an explanation that it belongs to the Sicilian wines (I, 27d [48, 59-60 KAIBEL]). Athenaeus also writes about wines from the Adrianós (I, 33a [59, 40 KAIBEL]) class, which are, however, listed among those produced on the peripheries of Italia and outside its borders. Therefore, it is possible that initially this passage closed the deliberations on Italic wines and, just like in the works by Dioscorides and Pliny, constituted a transition to the catalogue of non-Italic wines, which can be found within the same book of the Deipnosophistae. It begins with a classification of wines containing seawater (I, 32d [59, 14 KAIBEL]), and ends with a list of Egyptian wines (I, 33f [60, 33 KAIBEL]). ${ }^{41}$ For instance, cf. Galen, On the Doctrines of Hippocrates and Plato, IX, 6, 34, 1 - 46, 7, ed. P.H. DE LaCy, Berlin 1978 (cetera: Galen, De placitis Hippocratis et Platonis); Galeni de alimentorum 
he attributed to Hippocrates ${ }^{42}$. Let us add here that the general similarity of doctrines included in Corpus Hippocraticum, De materia medica, Naturalis historia and the Deipnosophistae implies that Sextius Niger also used the primary teachings on wine, which did not differ from the exposition contained within De diaeta in morbis acutis, and thus Hippocrates can be listed among the sources used by Sextius Niger.

Returning to the physician of Pergamon, however, one should conclude that, besides Sextius Niger and Hippocrates, Galen's own life experience shaped his oenological theory. He thus often mentioned wines from (his native) Asia, which could be illustrated with his personal observations of the effects possessed by alcoholic drinks produced near Aigai and Perparena, for example in De victu attenu$a n t e^{43}$. By and large, the output of Dioscorides, Pliny and Galen provides us with a relatively complete picture of the importance of wine in terms of consumption, production and therapeutics between the $1^{\text {st }}$ century and the early $3^{\text {rd }}$ century A.D.

The subject must have been significant and fashionable in medical circles, since - at approximately the same time as Dioscorides and later Galen - the role of wine in curative procedures was also discussed by Rufus of Ephesus $\left(1^{\mathrm{st}} / 2^{\text {nd }}\right.$ centuries

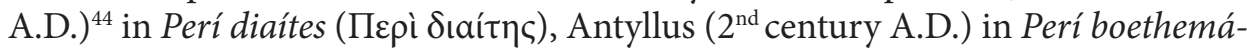

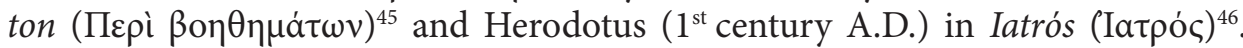
Interest in the issue did not wane at the end of the $2^{\text {nd }}$ century, as is evidenced by the fact that in the $4^{\text {th }}$ century, Philagrius wrote about wine in Perí hedéon

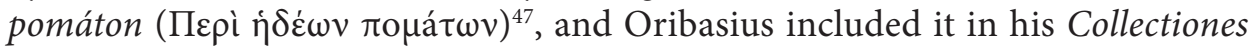

facultatibus libri III, 743, 1 - 745, 2 (reference to Hippocrates as an authority - 743, 14-15), [in:] Claudii Galeni opera omnia, vol. VI, ed. C.G. KüHn, Lipsiae 1823 (cetera: GALEN, De alimentorum facultatibus); Galen, De methodo medendi, 556, 3-5, vol. X (reference to Hippocrates as an authority); 830, 1 - 837, 15, vol. X; GALEN, De rebus boni malique suci, 800, 6 - 808, 7, vol. VI; Galen, De sanitate tuenda, 334, 5 - 339, 10, vol. VI (reference to Hippocrates as an authority - 335, 12, vol. VI); Galeni de victu attenuante, 92, 1 - 103, 3, ed. K. KALBFLEISCH, Leipzig-Berlin 1923 (cetera: GALEN, De victu attenuante).

${ }^{42}$ De diaeta in morbis acutis, 14, 1-33, [in:] Oeuvres completes d'Hippocrate, vol. II, ed. É. LitTré, Paris 1840 (cetera: De diaeta in morbis acutis). On the treatise, cf. J.M. WiLKIns, Hippokratic Corpus, Regimen (ca 430-370 BCE), [in:] The Encyclopedia..., p. 417.

${ }^{43}$ Galen, De victu attenuante, 102, 1 - 103, 3.

${ }^{44}$ For instance, Oribasii collectionum medicarum reliquiae, V, 7, 1, 1 - 7, 3; V, 9, 1, 1-3, 2; V, 12, 1, 1 - 3, 3, vol. I-IV, ed. I. RAeder, Lipsiae-Berolini 1928-1933 (cetera: Oribasius, Collectiones medicae). On Rufus of Ephesus, cf. J. Scarborough, Rufus of Ephesos (ca 70-100 CE), [in:] The Encyclopedia..., p. 720-721; M. LetTs, Rufus of Ephesus and the Patient's Perspective in Medicine, BJHP 22, 2014, p. 996-1020.

${ }^{45}$ Oribasius, Collectiones medicae, V, 29, 1,1 - 10, 6. On Antyllus, cf. I. Bio, Antyllos, [in:] Antike medizin..., col. 62-63; A. TouwaIde, Antullos (100-260 CE), [in:] The Encyclopedia..., p. 101-102.

${ }^{46}$ Oribasius, Collectiones medicae, V, 27, 1, 1 - 23, 9. On Herodotus, cf. M. Stamatu, Herodot [2], [in:] Antike medizin ..., col. 405-406; A. TouwaIde, Hērodotos (Pneum., of Tarsos?) (70-100 CE), [in:] The Encyclopedia..., p. 383-384.

${ }^{47}$ Oribasius, Collectiones medicae, V, 17, 1, 1 - 11, 4. On Philagrius, cf. R. Masullo, Philagrios, [in:] Antike medizin..., col. 693-694; J. Scarborough, Philagrios of Épeiros (300-340 CE), [in:] The Encyclopedia..., p. 643-644. 
medicae ${ }^{48}$. What should also be added is that in the $6^{\text {th }}$ century, a catalogue of therapeutic wines was noted in Book III of Iatricorum libri by Aëtius of Amida ${ }^{49}$, and in the $7^{\text {th }}$ century, Paul of Aegina included the theory of wine in his encyclopaedia entitled Epitome ${ }^{50}$. Finally, in the $10^{\text {th }}$ century, the author of Geoponica devoted a great amount of his attention to wine, writing about it in as many as two books (VII and VIII) of his treatise ${ }^{51}$.

\section{Seven formulas}

The analysis of De materia medica with regard to information on wine should commence with a statement that Dioscorides perceived it both as a foodstuff ${ }^{52}$ and

${ }^{48}$ Oribasius indicated Dioscorides as his source of knowledge - OrIBAsIUs, Collectiones medicae, V, 25, 1, 1 - 47, 3. On Oribasius, cf. B. BALdwin, The Career of Oribasius, AClas 18, 1975, p. 85-97;

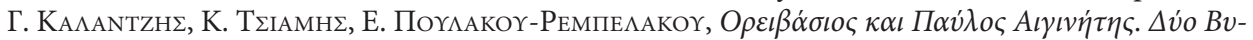

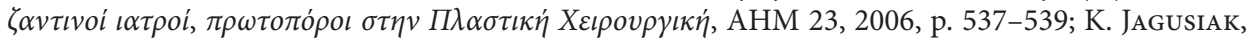
M. Кокозzко, Życie i kariera Orybazjusza w świetle relacji źródłowych, PNH 10, 2011, p. 5-21.

${ }^{49}$ Aetii Amideni libri medicinales I-VIII, III, 58, 1 - 74, 5, ed. A. OlIVIERI, Lipsiae-Berolini 1935-1950 (cetera: AëTIUs of AmidA, Iatricorum libri). He compiled a selection of recipes for therapeutic wines, as found in the output of Theon, whose professional activity is dated between the $1^{\text {st }}$ and $6^{\text {th }}$ centuries A.D. On Theon, cf. K. Dickson, Theōn of Alexandria (Med. II) (ca 300-500 CE), [in:] The Encyclopedia..., p. 795. On Aëtius of Amida, cf. R. Romano, Aezio Amideno, [in:] Medici bizantini. Oribasio di Pergamon. Aezio d'Amida. Alessandro di Tralle. Paolo d'Egina. Leone medico, ed. A. GARzya, R. de lucia, A. Guardasole, A.M. Ieraci Bio, M. Lamagna, R. Romano, Torino 2006, p. 255-261; J. Scarborough, Aetios of Amida (500-550 CE), [in:] The Encyclopedia..., p. 38-39; J. Scarborough, Theodora, Aetius of Amida, and Procopius: Some Possible Connections, GRBS 53, 2013, p. 742-762.

${ }^{50}$ Paulus Aegineta, I, 95, 1, 1-28, vol. I-II, ed. I.L. Heiberg, Lipsiae-Berolini 1921-1924 (cetera: PAul of Aegina, Epitome). On Paul of Aegina, cf. R. Gurunluoglu, A. Gurunluoglu, Paul of Aegina:

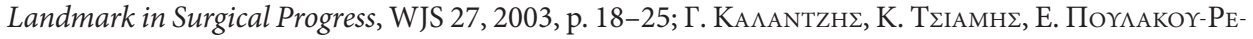

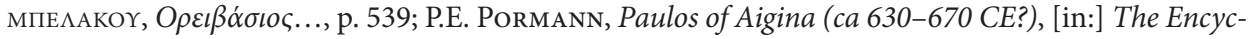
lopedia..., p. 629.

${ }^{51}$ For the divagations herein, it is important that in both books we find a great amount of data on the therapeutic effects of wine, and in Book VIII - a catalogue of therapeutic wines, cf. Geoponica sive Cassiani Bassi Scholastici de re rustica eclogae, VIII, 1, 1 - 22, 3, rec. H. ВЕСКH, Lipsiae 1895 (cetera: Geoponica).

${ }^{52}$ Wine as an element of diet in the ancient Mediterranean, cf. N. Purcell, Wine and Wealth in Ancient Italy, JRS 75, 1985, p. 1-19 (13-15 in particular); P.E. McGovern, Ancient Wine. The Search for the Origins of Viniculture, Princeton 2003, p. 70-72; J.P. Alсоск, Food in the Ancient World, Westport-London 2006, p. 92-95; R. LaURence, Roman Passions. A History of Pleasure in Imperial Rome, London 2010, p. 109-114; M. WĘCOWsKI, Sympozjon czyli wspólne picie. Początki greckiej biesiady arystokratycznej (IX-VII wiek p.n.e.), Warszawa 2011, p. 50-56; T. Boulay, Wine Appreciation in Ancient Greece, [in:] A Companion to Food in the Ancient World, ed. J. Wilkins, R. NADEAU, Chichester 2015, p. 273-282; R. Hunter, D. Koukouzika, Food in Greek Literature, [in:] A Companion to Food..., p. 26-29; J.F. Donahue, Culinary and Medicinal Uses of Wine and Olive Oil, [in:] A Companion..., p. 608-609; D.L. Thurmond, From Vines to Wines in Classical Rome. A Handbook of Viniculture and Oenology in Rome and the Roman West, Leiden-Boston 2017, p. 218-235. Wine as

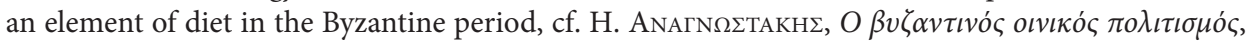


medicament ${ }^{53}$, which was concordant with the binding medical doctrine of the

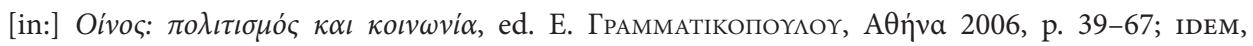

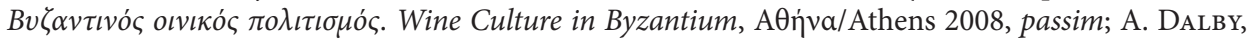
Tastes of Byzantium. The Cuisine of a Legendary Empire, London 2010, p. 85-104; I. ANAGNostakis, The Sweet Wine of Bithynia in the Byzantine Era, [in:] Of Vines and Wines. The Production and Consumption of Wine in Anatolian Civilizations through the Ages, ed. L. Thys-ŞENocaK, Leuven-ParisBristol 2017, p. 93-117.

${ }^{53}$ This opinion was shared by others. For instance, the physician of Pergamon, as a follower of Hippocrates's ideas, devoted the whole extract to this issue within his main and most significant work on dietetics (GALEN, De alimentorum facultatibus, 743, 1-13, vol. VI). As stems from the work, medical circles of the time had no doubt regarding the nutritive properties of wine. The fact that wines were included in Dioscorides' De materia medica and Galen's De simplicium medicamentorum temperamentis ac facultatibus ( $88,4-7$, vol. XII) indicates that both medical authors never questioned their therapeutic properties. As far as modern science is concerned, it must be stated that although numerous studies have been devoted to the history of wine, the drink as a medicament has not been a common subject of modern scientific research. Whenever considering medical applications of wine, scholars have so far focused primarily on the characteristics of wine and its applications in the treatises constituting Corpus Hippocraticum, as can be illustrated by such studies as R. Alessi, Le vin dans les Épidémies d'Hippocrate, [in:] Vin et santé en Grèce Ancienne, Actes du Colloque organisé à l'Université de Rouen et à Paris (Université de Paris IV Sorbonne et ENS) par l'UPRESA 8062 du CNRS et l'URLLCA de l'Université de Rouen, 28-30 septembre 1998, ed. J. Jouanna, L. Villard, Athènes 2002, p. 105-112; M. López SALVÁ, Efectos patológicos del vino en el Corpus Hippocraticum, [in:] Le normal et le pathologique dans la Collection hippocratique, Actes du $X^{\text {ème }}$ colloque international hippocratique, Nice, 6-8 octobre 1999, ed. A. Thivel, A. Zucker, Nice 2002, p. 523-537; D. MiCALELla, Vino e amore: Ippocrate, QUCC 24, 1977, p. 151-155; L. VILlaRd, Le vin et les femmes: un text méconnu de la collection hippocratique, RÉG 110, 1997, p. 362-380; L. VILLARD, Tant de vin pour soigner les femmes, [in:] Aspetti della terapia nel Corpus Hippocraticum. Atti del IX Colloque international hippocratique (Pisa, 25-29 settembre 1996), ed. I. Garofalo, A. Lami, D. Manetti, A. RoselLI, Firenze 1999, p. 219-234. Basically, the output of Jacques JouAnna focuses on the same collection (Le vin et la médecine dans la Grèce ancienne, RÉG 109, 1996, p. 410-434 (= IDEM, Wine and Medicine in Ancient Greece, [in:] Greek Medicine from Hippocrates to Galen. Selected Papers, ed. P. van DER EIJK, trans. N. Allies, Leiden-Boston 2012, p. 173-193), although he also provides some remarks on later medicine. When it comes to the pre-Greek tradition of medical applications of wine, we are familiar with one attempt to collect basic information on the matter - L.E. GRIVETTI, Wine: the Food with Two Faces, [in:] The Origins and Ancient History of Wine, ed. P. McGovern, S.J. Flemming, S. Katz, Amsterdam 1996, p. 9-22. Monographs regarding individual authors from outside the Corpus Hippocraticum are scarce and incomplete. Some attention is devoted to Galen - D. BÉGUIN, Le vin médecin chez Galien, [in:] Vin..., p. 141-154; V. Boudon, Un médecin oenophile: Galien et le vin de Falerne, [in:] Vin..., p. 155-163. There is also a study on the position of wine within the doctrines by Aretaeus of Cappadocia - J. Jounnna, Le vin chez Arétée de Cappadoce, [in:] Vin..., p. 113-126. One can also trace some interest in the medical threads of wine and its properties in the works of Homer and other poets of Archaic Greece (D. Arnould, Du bon usage du vin chez Homère et dans la poésie archaïque, [in:] Vin..., p. 7-10), in the output of Horace (A. La Penna, Il vino di Orazio: nel modus e contro il modus, [in:] In vino veritas, ed. O. MurraY, M. Tecuşan, Oxford 1995, p. 266-282). Somewhat similar issues are discussed in a monograph on Falernian wine - A. LA Penna, Immortale Falernum. Il vino di Marziale e dei poeti latini del suo tempo, Ma 51, 1999, p. 163-181. As far as the role of wine in the post-Galenic and early Byzantine periods is concerned, cf. M. Кокоszко, Smaki Konstantynopola, [in:] Konstantynopol - Nowy Rzym. Miasto i ludzie w okresie wczesnobizantyńskim, 
time ${ }^{54}$. The scope of information available in De materia medica is broad, since the author preserved a pool of data on the properties of wine ${ }^{55}$, including its branded (identified by means of appellation d'origine) ${ }^{56}$ and unbranded (generic) ${ }^{57}$ types, compiled a catalogue of aromatised therapeutic wines (which contains formulas for the wines analysed herein $)^{58}$, and provided a substantial amount of other detailed information. Since our deliberations leave us little or no space to discuss every aspect of Dioscorides' teachings on wine, we shall focus exclusively on the main constituents of his account, which are important for the analysis of the text in the context of our research subject.

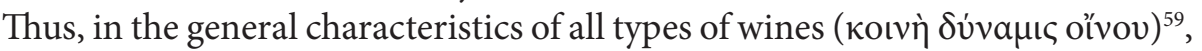
we can read that they contain a certain element of sharpness or acidity. Pure and undiluted ones are, by nature, warming and easily digestible (and they facilitate digestion), beneficial for the stomach, and nutritious. They whet the appetite, make falling asleep easier, strengthen the body and result in a desired skin pigmentation ${ }^{60}$. What must be added here is that Dioscorides was significantly more precise in his deliberations, conditioning the effect of wine on its age (discussing a full range of wines, from old to young $)^{61}$, colour (from white to black) ${ }^{62}$, and taste (from dry to sweet) ${ }^{63}$.

In sum, this is a typical classification which combines the effects attributed to wine by dieticians and pharmacologists. Importantly, its content does not diverge from the canon that we can see in the works by other ancient and then Byzantine authors, and proves that, in the $1^{\text {st }}$ century A.D., a body of works on the science of wine already existed, and thus, that the doctrine had been fully developed before Dioscorides and even Sextius Niger began to write their works. And since the doctrine does not differ from the oenological knowledge available in De diaeta

ed. M.J. Leszka, T. Wolińska, Warszawa 2011, p. 564-569; M. Koкoszko, Z. RzeźNicka, Malábathron ( $\mu \alpha \lambda \dot{\alpha} \beta \alpha \theta \rho o v)$. Kilka uwag o roli Cinnamomum tamala $w$ kuchni i medycynie antyku i Bizancjum w okresie pomiędzy I a VII wiekiem, PNH 15, 2016, p. 30-31; IIDEM, Malabathron ( $\mu \alpha \lambda \dot{\alpha} \beta \alpha \theta \rho o v)$ in Ancient and Early Byzantine Medicine and Cuisine, MS.AS 30, 2018, p. 583, 592.

${ }^{54}$ This doctrine had been binding since the times of Hippocrates, and consolidated by Galen. Cf. M. Koкоszкo, K. Jagusiak, Z. Rzeźnicka, Cereals of Antiquity and Early Byzantine Times. Wheat and Barley in Medical Sources, trans. K. Wodarczyk, M. Zakrzewski, M. Zytka, Łódź 2014 [= BL, 20], p. 7-28 (7-12 in particular); IIDEM, Dietetyka i sztuka kulinarna antyku i wczesnego Bizancjum (II-VII w.), Część I, Zboża i produkty zbożowe w źródłach medycznych antyku i wczesnego Bizancjum, Łódź 2014 [= BL, 16], p. 5-26, (6-10 in particular).

${ }^{55}$ Cf. below. For a detailed analysis, cf. M. Kокоszко, Enologia..., p. 49-62.

${ }^{56}$ Dioscorides, De materia medica, V, 6, 6, 1 - 9, 5.

${ }^{57}$ Dioscorides, De materia medica, V, 6, 14, 1-9, 2, 11.

${ }^{58}$ Dioscorides, De materia medica, V, 20, 1, 1-73, 1, 4.

${ }^{59}$ Dioscorides, De materia medica, V, 6, 10, 1 - 13, 8.

${ }^{60}$ Dioscorides, De materia medica, V, 6, 10, 1-4.

${ }^{61}$ Dioscorides, De materia medica, $\mathrm{V}, 6,1,1-7$.

${ }^{62}$ Dioscorides, De materia medica, V, 6, 2, 1-5.

${ }^{63}$ Dioscorides, De materia medica, V, 6, 2, 6 - 3, 7 . 
in morbis acutis, we may assume that its framework was formed during the early stages of the development of Greek medical theory.

The extracts on therapeutic wines of interest to us can be found in Book V of De materia medica, and more specifically, in the catalogue of aromatised wines, i.e. potations with a specific curative effect produced by the addition of plantbased (active in a given range) ingredients to wine must or wine. Appearing first

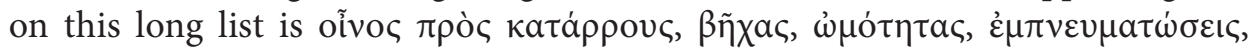

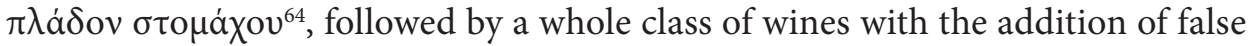
hellebore, i.e. six variants of the helleborites ( $\dot{\varepsilon} \lambda \lambda_{\varepsilon} \beta$ opi $\left.\tau \eta \varsigma\right)$ wine ${ }^{65}$.

As far as the second category of therapeutic wines is concerned, the first formula recommended using a measurement unit called choús (Хoṽ $)^{66}$ of wine must with the addition of seawater, and twelve drachm $\mathrm{s}^{67}$ of ground black false hellebore, wrapped in thin canvas and immersed in liquid. Once the wine ceased to ferment, it was poured into vessels in which it was to be stored (until served to patients) ${ }^{68}$.

The second formula involved the application of a single choús of wine - without the addition of salt water - to which fifteen (or fourteen) drachms of coarsely crumbled false hellebore were added and left for several days. The wine was

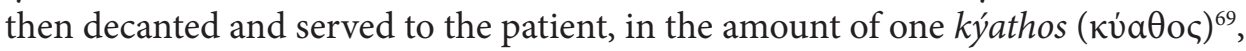
together with bath-house water ( $\dot{\kappa} \kappa \beta a \lambda \alpha v \varepsilon i o v)$, in order to induce a purgation of the digestive system, but not before the recipient had brought up the main meal

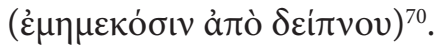

Another formula tells of twenty drachms of false hellebore, twelve drachms of camel grass, and thirteen drachms of Syrian spikes. The plants were wrapped

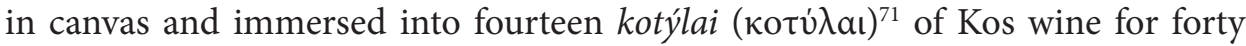
days. Thus prepared, the wine was decanted and administered to the patient in the

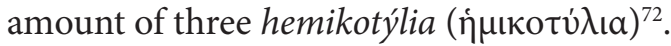

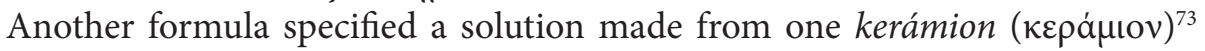
of wine must and two xéstai ( $\xi \dot{\varepsilon} \sigma \tau \alpha \mathrm{l})^{74}$ of boiled seawater, in which half a litra $(\lambda i \tau \rho \alpha)^{75}$ of white false hellebore was immersed for forty days, after which time the wine was decanted and used for various treatments ${ }^{76}$.

\footnotetext{
${ }^{64}$ Dioscorides, De materia medica, $\mathrm{V}, 55,1,1-6$.

${ }^{65}$ Dioscorides, De materia medica, V, 72, $1,1-3,9$.

${ }^{66}$ Choús $=3.77$ litres.

${ }^{67}$ Drachm $=4.32$ grams.

${ }^{68}$ Dioscorides, De materia medica, V, 72, 1, 1-3.

${ }^{69}$ Kýathos $=0.045$ litres.

${ }^{70}$ Dioscorides, De materia medica, V, 72, 1, 3 - 2, 1 .

${ }^{71}$ Kotýle $=0.27$ litres.

${ }^{72}$ Dioscorides, De materia medica, V, 72, 2, 1-4. Hemikotýlion = half kotýle.

${ }^{73}$ Kerámion $=26.2$ litres.

${ }^{74}$ Xéstes $=0.54$ litres.

${ }^{75}$ Litra $=0.28$ litres.

${ }^{76}$ Dioscorides, De materia medica, V, 72, 2, 4-7.
} 
The fifth formula incorporated twelve drachms of false hellebore, four drachms of soda (i.e. sodium carbonate $\left[\mathrm{Na}_{2} \mathrm{Co}_{3}\right]$ ), and twelve kotýlai of wine must. The hellebore was kept in the solution for fifteen days, then the liquid was decanted, but it needed six more months before it could be administered, for instance, to abort a foetus.

In order to prepare the last variant of the therapeutic wine, to one metretés $(\mu \varepsilon \tau \rho \eta \tau \eta \varphi))^{77}$ of must - made from dried (and still unplucked) grapes - twenty drachms of chalk were added and the solution was left for two days, after which time one had to immerse a bundle made from thirty drachms of false hellebore, the same amount of camel grass and sweet flag, as well as three quarters of a choinix $(\chi 0 \tilde{v} \nu 1 \xi)^{78}$ of juniper berries, and a drachm of myrrh and saffron wrapped into a small cloth. The solution was then left for forty days. Next, the wine was decanted, diluted with water, and served to the patient, in the amount of two or three mugs. This drink was supposed to remove the post-natal remains from the body of puerperae or women who had miscarried. It would also induce miscarriages and was attributed with the power to counteract hysterical dyspnoea ${ }^{79}$.

Having explained the formulas for wine with the addition of false hellebore, we may now return to the very first of the recipes, in which Dioscorides indicates that, during his times, there was a wine prepared to address such ailments as a runny nose, cough, indigestion, bloating, and an excess of humidity within the stomach. The formula for this wine listed two drachms of myrrh, one drachm of white pepper, six drachms of iris, three drachms of dill, and six xéstai of wine. Solid ingredients were crumbled, wrapped in a canvas cloth, and immersed in wine for three days, after which time the liquid was decanted and poured into a bottle. One $k_{y}$ athos ${ }^{80}$ of the undiluted medicament was administered to the patient once he had come back from a walk.

Proceeding to analyse the explained extracts, we must state that wines within the class of helleboritai had a purgative effect, in every sense of the word. This may not have been distinctively emphasised in the scrutinised extract of De materia medica, but it stems unambiguously from Dioscorides' characteristics of both the false hel-

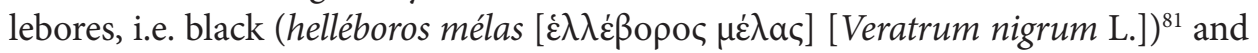

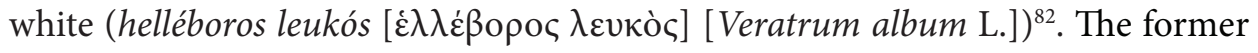

\footnotetext{
${ }^{77}$ Metretés $=39.29$ litres.

${ }^{78}$ Choiní $=1.1$ litres.

${ }^{79}$ Dioscorides, De materia medica, V, 72, 3, 1-9.

${ }^{80}$ Dioscorides, De materia medica, V, 55, 1, 1-6.

${ }^{81}$ Dioscorides, De materia medica, IV, 162, 1, $1-4,11$.

${ }^{82}$ Dioscorides, De materia medica, IV, 148, 1, $1-3$, 10. The pharmacological properties of both hellebore species were also discussed by Pliny the Elder (Naturalis historia, XXV, 48, 1-61, 11) and GALEN (De simplicium medicamentorum temperamentis ac facultatibus, 874, 1-9, vol. XI). Analogical data can be found in treatises by the early Byzantine physicians, cf. Oribasius, Collectiones medicae, XI, $\varepsilon, 7,1$ - 8, 9; AётIUs of AmidA, Iatricorum libri, I, 140, 1-9. Since the extracts on hellebore in
} 
induced purgation through rectal excretion ${ }^{83}$, while the latter had an emetic effect $^{84}$. Both were also used as abortifacient medicaments ${ }^{85}$. It should be added that hellebores were widely available in the Mediterranean Basin and commonly used in numerous treatments ${ }^{86}$, which means that their application only tells us of therapeutic methods practised in the $1^{\text {st }}$ century A.D., without any new information that could be significant for this analysis.

As for the applications of individual formulas, we presume that the first three concern purgation via the gastrointestinal system, as this effect was explicitly

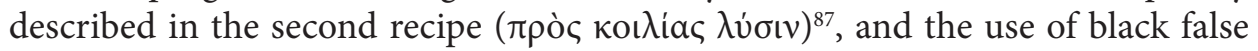
hellebore in the said recipe also corresponds with the information provided within its description in Book IV ${ }^{88}$. The next three formulas (Nos. 4-6) are, on the other hand, recipes for wine with an abortifacient effect ${ }^{89}$. Omitted in the fourth formula, this property is demonstratively indicated in the fifth and sixth. Since Pliny recorded the information that it was white false hellebore that was customarily added to sweet wine ${ }^{90}$ (which, particularly in the Roman civilisation, was considered more appropriate for women ${ }^{91}$ ), this sentence can be interpreted as an additional argument indicating that white hellebore was used in the sixth recipe, which also included white wine. Thus, if white hellebore appeared in the fourth and sixth formulas, it is more than logical to assume that it was also used in the fifth recipe, and all the more so, since we can presume that all three formulas were, as a matter of fact, medicaments for women and were related to their reproductive functions.

De materia medica and Naturalis historia are so similar, we can presume that they had been derived from the same source, i.e. the work by Sextius Niger. A crucial argument that supports this thesis is the fact that his name was listed within the index of authors for Book XXV, cf. PLINY, Naturalis historia, I, 25b, 2.

${ }^{83}$ Dioscorides, De materia medica, IV, 162, 2, 7-8.

${ }^{84}$ Dioscorides, De materia medica, IV, 148, $2,4$.

${ }^{85}$ Dioscorides, De materia medica, IV, 148, 2, 6 (white false hellebore); IV, 162, 3, 2-3 (black false hellebore). On abortion in the ancient world, cf. J.M. RidDLE, Conception and Abortion from the Ancient World to the Renaissance, Cambridge, Mass.-London 1992, p. 16-107; J.G. YoungER, Sex in the Ancient World from A to Z, London-New York 2005, p. 1.

${ }^{86}$ Cf. J.M. Riddle, Dioscorides..., p. 111-115; A. DAlBy, Food in the Ancient World from A to Z, London-New York 2003, p. 174-175; E. Lev, Z. Amar, Practical Materia Medica of the Medieval Eastern Mediterranean according to the Cairo Genizah, Leiden-Boston 2008, p. 417-418; M. Do SAMEIRO Barroso, The Hellebore, the Plant Beloved by the Greeks: the Reasons Behind a Myth, Ves 21, 2015, p. 30-37; M.A. Maieron, On the Hellebore Trail an Anthropological Research into Madness, MedHis 2, 2018, p. 5-18. On the hellebore in the Mediterranean, cf. J.E. Raven, Plants and Plant Lore in Ancient Greece, Oxford 2000, p. 80-82.

${ }^{87}$ Dioscorides, De materia medica, V, 72, 1, $3-2,1$.

${ }^{88}$ Dioscorides, De materia medica, IV, 162, 1, 1 - 4, 11 (purgative properties - IV, 162, 2, 6 [кaӨaípeı

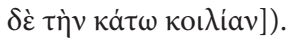

${ }^{89}$ On abortifacient wines in Dioscorides' work, cf. J.M. RiddLe, Conception..., p. 54-55.

${ }^{90}$ PLINY, Naturalis historia, XXV, 59, 6.

${ }^{91}$ This thought is developed below. 
Finally, we can state that the section devoted to wines seasoned with hellebores was compiled in accordance with the principle of dividing them by their fundamental therapeutic effects. The first three, based on the properties of black false hellebore, have a very strong purgative effect ${ }^{92}$ on the digestive system and do not specify the patient's gender, while the next three are aimed at biologically mature women, and their effects are connected with the patient's motherhood.

Let us now scrutinise the very first formulas from both groups. The two medicaments had an extraordinarily simple composition, since they only contain generic wine and black (the purgative recipe) or white (the abortifacient formula) false hellebore, respectively. And both were made in accordance with a traditional basic recipe, i.e. one that needs no further explanation, since it involves commonly known and accessible ingredients. Therefore, these formulas were characterised by lesser complexity and, consequently, by lower production costs. And thus, they were, to some extent, formulas for the poorest, which made the final product available to all. The remaining recipes from both groups were their expanded versions, but with the same main active substances.

The rationality of this disquisition is reinforced by the fact that, in both classes, the third therapeutic wine (i.e. helleborites in recipes Nos. 3 and 6) becomes more complex structurally, and the two formulas involve imported ingredients, whose prices must have been relatively high. Thus, they are medicaments intended for those who could afford them, i.e. for patients of at least moderate means.

To support our statements with evidence, we would like to draw the reader's attention to the fact that the third formula for the purgative helleborites lists at least

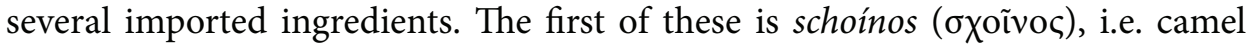
grass (Cymbopogon schoenanthus (L.) Spreng.), which - according to Dioscorides

\footnotetext{
${ }^{92}$ In the case of patients who needed milder agents, such remedies as radish or milk were administered. Cf. M. Кокоszко, Rzodkiew (Raphanus L) w wybranych źródłach antyku i Bizancjum, [in:] Lek rośliny, vol. IV, Produkty pochodzenia roślinnego w lecznictwie, dietetyce, kosmetyce, ekonomice $i$ kulturze popularnej, ed. B. PŁonka-Syroka, A. Syroka, Wrocław 2015, p. 15-33; idem, Galaktologia terapeutyczna ( $\gamma \alpha \lambda \alpha \kappa \tau o \lambda o \gamma i \alpha$ i $\alpha \tau \iota \kappa \eta \dot{)}$ Galena zawarta $w$ De simplicium medicamentorum temperamentis ac facultatibus, PNH 14, 2015, p. 5-23; М. Кокоszко, J. DуваєА, Medyczna nauka o mle-

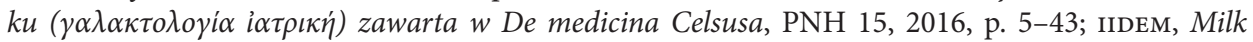
in medical theory extant in Celsus' De medicina, JFSE 6, 2016, p. 267-279; Z. RzEŹNICKA, Kilka stów o mleku i jego przetworach, [in:] Z. RzeźnıcкA, M. Kокоszко, Dietetyka i sztuka kulinarna antyku i wczesnego Bizancjum (II-VII w.), Część III, Ab ovo ad yá $\alpha$. Jajka, mleko i produkty mleczne w medycynie i w sztuce kulinarnej (I-VII w.), Łódź 2016 [= BL, 28], p. 61; EADEM, Milk and Dairy Products in Ancient Dietetics and Cuisine according to Galen's De alimentorum facultatibus and Selected Early Byzantine Medical Ttreatises, [in:] Latte e latticini. Aspetti della produzione e del consume nella società miditerranee dell' Antichità e del Medioevo. Atti del Convegno Internazionale di Studio promosso dall' IBAM - CNR e dall'IRS - FNER nell' ambito del Progetto MenSALe Atene, 2-3 ottobre 2015, ed. I. ANAgnostakis, A. Pellettieri, Lagonegro 2016, p. 51, 60; M. Kokoszko, K. Jagusiak, Z. Rzeźnicka, J. DybaєA, The Radish (Raphanus L.) in Selected Sources from Antiquity and the Byzantine Period, Епо 26, 2018, p. 79-91.
} 
- grew in Arabia, so in the south of the Arabian Peninsula. Therefore, it must have been shipped from a long distance and very expensive ${ }^{93}$. Its application within the formula was based on the pharmacological knowledge of the time. Since the characteristics of the plant clearly indicate that it facilitates digestion, it was served with drinks to alleviate gastric disorders, administered for nausea, and had a purgative diuretic effect on the body ${ }^{94}$.

Another ingredient, whose name indicates its importation, was stáchys Syriakós

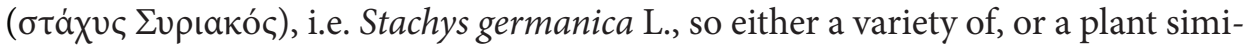
lar to, downy woundwort ${ }^{95}$. Its Syrian origin suggests that it was also an imported additive, so not as affordable as false hellebore ${ }^{96}$, and its properties perfectly complemented the other ingredients of the medicament ${ }^{97}$.

Within the formula, there is one more condition implying that it was aimed at wealthier recipients. Namely, Dioscorides specifically recommends the use of Kos wine, while in the first and second recipe, he never stipulates any particular type of wine.

It should be explained here that the toponymy determining the origin of a wine was always telling and usually indicated its quality, also suggesting its high price. In order to support our conclusion, it is worth referring to Galen, who in De rebus boni malique suci, for instance, pointed out that winemaking was common in the Mediterranean Basin, and from his words, we should conclude that the vast majority of wines available on the market were young wines. Galen also suggested that in order to remain healthy, one should drink those thin by nature, listing such Italic

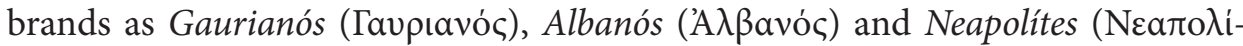

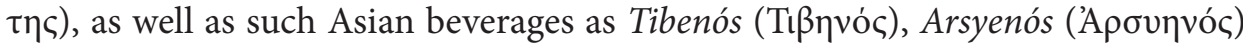

${ }^{93}$ Dioscorides, De materia medica, I, 17, 1, 1-4. According to The Edict on Maximum Prices by Diocletian, a pondus (27.3 g) of camel grass cost 50 denarii, cf. Edictum Diocletiani et Collegarum de pretiis rerum venalium, 36, 123, vol. I-II, ed. M. GIACCHERo, Genova 1974 (cetera: Edictum Diocletiani). On the presence of the plant, cf. I. Erard-Cerceau, Végétaux, parfums, et parfumeurs à l'époque mycénienne, SMEA 28, 1990, p. 268.

${ }^{94}$ Dioscorides, De materia medica, I, 17, 1, $1-2$, 9. The medical properties of camel grass were also discussed by GALEN (De simplicium medicamentorum temperamentis ac facultatibus, 136, 18-137, 13, vol. XII). Analogical data can be found in treatises by the early Byzantine physicians, cf. Oribasius, Collectiones medicae, XV, 1, 18, 71, 1 - 72, 1; AётIUs of AmidA, Iatricorum libri, I, 384, 1-5; PAUL of Aegina, Epitome, VII, 3, 18, 233-237.

${ }^{95}$ On the plant, cf. J. ANdré, Lexique des termes de botanique en latin, Paris 1956, p. 302; IDEM, Le noms de plantes dans la Rome antique, Paris 1985, p. 247.

${ }^{96}$ The pharmacological properties of the plant called oTáxvৎ were discussed by Dioscorides ( $D e$ materia medica, III, 106, 1, 1-6) and GALEN (De simplicium medicamentorum temperamentis ac facultatibus, 129, 1 - 130, 2, vol. XII). Analogical data can be found in treatises by the early Byzantine physicians, cf. Oribasius, Collectiones medicae, XLVIII, 46, 1, 1 - 5, 2; Paul of Aegina, Epitome, VII, 3, 18, 157-159.

${ }^{97}$ We may conclude that the plant possessed some properties stimulating the purgation of the body, since the decoction prepared from its leaves was administered orally to induce menstruation, cf. Dioscorides, De materia medica, III, 106, 1, 5-6. 
and Titakadzenós (ТiтакаØ̆vóৎ). At the same time, he remarked that numerous wines produced in the Mediterranean world were not as commonly known as the aforementioned ones, since they could not be exported as they would not survive the long voyage $e^{98}$. And it was unbranded wines that Dioscorides had in mind when writing down his recipes. Thus, while the very first formula for a purgative wine recommended the application of wine must (gleúkos [ $\gamma \lambda \varepsilon \tilde{u} \kappa o \varsigma]$ ), i.e. merely a staple normally used to make young wine, and the second recipe included a freshly produced, and thus, still sweet generic wine ${ }^{99}$ with no additives ${ }^{100}$, the third one specified the wine by means of toponymy, i.e. a sui generis appellation d'origine.

The popularity of the wine from Kos as a brand is indicated by source data. Marcus Porcius Cato mentioned it several times in De agri cultura, even providing the reader with a recipe for its production ${ }^{101}$. And he would not have done so if - in the second part of the $2^{\text {nd }}$ century B.C. - there had been no demand in Italia to produce a native version of this beverage. Therefore, local production of the wine analogical to the drink made on Kos either stemmed from an inability to satisfy the demand for the drink, or was conditioned by high prices of the imported original product.

The wine of Kos (and of Klazomenai) was also mentioned by Dioscorides in the catalogue of branded wines, where he wrote that it was made from a significant portion of seawater (tethalassoménos [ $\tau \varepsilon \theta \alpha \lambda \alpha \sigma \sigma \omega \mu \varepsilon \dot{v} \sigma \varsigma]$ ), and thus, it would

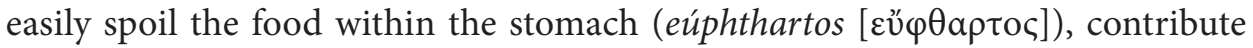
to the production of gases (pneumatódes [ $\pi v \varepsilon v \mu a \tau \omega \dot{\delta} \eta \varsigma]$ ), cause problems with-

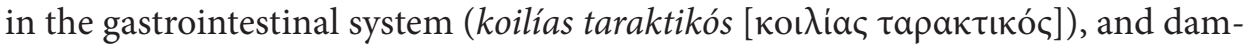

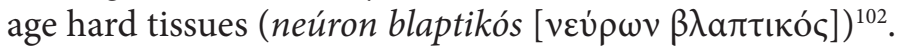

The description also points to one more fact. Such wine did not belong to the class of wines characterised by high therapeutic values, i.e. to the most prized and valuable drinks. Instead, as stems from Dioscorides' account, it occupied the bottom of the wine rank. It is worth noting that De materia medica contains a general description of wines with salt water ${ }^{103}$, together with some detailed information

\footnotetext{
${ }^{98}$ Galen, De rebus boni malique suci, 806, 2 - 806, 14, vol. VI.

${ }^{99}$ Wines lose their sweetness in the course of progressing alcoholic fermentation.

${ }^{100}$ We can only assume that it is wine, since the recipe contains no information on the fermentation of the therapeutic beverage.

${ }^{101}$ M. Porci Catonis de agri cultura, 112, 1, 1 - 113, 2, 7, rec. H. KeIL, Lipsiae 1895 (cetera: CATo, De agri cultura). On the author, cf. P. Thibodeau, M. Porcius Cato of Tusculum (185-149 BCE), [in:] The Encyclopedia..., p. 686-688. A recipe for the wine from Kos was also provided by Columella, cf. Lucius Iunius Moderatus Columella, On Agriculture in Three Volumes, Books 10-12 and De arboribus, XII, 37, vol. III, trans. E.S. Forster, E.H. Heffner, London-Cambridge 1955 (cetera: Columella, De re rustica). On the author, cf. R.H. Rodgers, L. Iunius Moderatus Columella of Gadess (ca 40 - ca 70 CE), [in:] The Encyclopedia..., p. 456-457. Analogous recipe can also be found in Geoponica (VIII, 24).

${ }^{102}$ Dioscorides, De materia medica, V, 6, 9, 5-7.

${ }^{103}$ Dioscorides, De materia medica, V, 6, 3, 4-7.
} 
on how to prepare them ${ }^{104}$. One should also add that the amount of attention devoted to such beverages implies their important position on the Mediterranean wine market in the $1^{\text {st }}$ century A.D. Also worth noting is the fact that the same wine is found in Pliny's Naturalis historia ${ }^{105}$, and the extract devoted to it is quite interesting, as it suggests that, during his times, Greek wines were considered outstanding on the market and applied in ars medica.

The latter remark is very instructive for historians of medicine, since it leads us to the conclusion that Pliny's source of knowledge had medical provenance, which ideally corresponds with the hypothesis that it may have been the treatise compiled by Sextius Niger. As far as other evidence of correct identification of the source authority is concerned, a comment on the ageing of wines exported from Italia is of crucial importance. We learn that they had to be matured for seven years prior to being considered drinkable ${ }^{106}$, and the same remark can be found in Dioscorides' work ${ }^{107}$, which indicates that both authors used the same source text, which can be identified as Perí hýles.

The wine of Kos was also known to Galen, who mentions it when describing a formula (composed by Asclepiades of Bithynia) for a mouth wash administered to treat bad teeth ${ }^{108}$. However, Galen never mentioned this brand in his wine catalogues, which may suggest that it had already ceased to belong to this class by the second half of the $2^{\text {nd }}$ century A.D.

Nevertheless, the preserved data entitles us to state that since the times of Dioscorides, wines with seawater, including the Kos wine, were imported to various markets of the Mediterranean world, and thus their prices were likely to exceed the charges for wine must or local brands of generic young wine.

Having conducted the analysis of the third recipe, let us now scrutinise the sixth formula for helleborites. Once we have taken into account the information it conveys, we have to expand our list of expensive ingredients - already present in the aforementioned recipes for wines with false hellebore - with sweet flag, saffron, and myrrh, leaving out juniper, whose berries Dioscorides considered to be a native and easily available foodstuff ${ }^{109}$. It should, however, be emphasised that

\footnotetext{
${ }^{104}$ Dioscorides, De materia medica, V, 19, 1, 1 - 2, 6.

${ }^{105}$ Pliny, Naturalis Historia, XIV, 77, 1 - 79, 4.

${ }^{106}$ PLINY, Naturalis Historia, XIV, 79, 4-5.

${ }^{107}$ Dioscorides, De materia medica, V, 6, 12, 5-6. What is worth noticing is the fact that identical

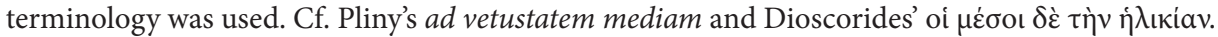
${ }^{108}$ Galeni de compositione medicamentorum secundum locos libri X, 866, 18 - 867, 10, vol. XII, [in:] Claudii Galeni opera omnia, vol. XII-XIII, ed. C.G. KüHN, Lipsiae 1826-1827.

${ }^{109}$ In his description of juniper, Dioscorides did not mention that it was an imported plant, and thus, we can assume that it was a common element of the flora within the regions of the Mediterranean Basin that he knew (De materia medica, I, 75, 1, 1-10). The use of a possessive pronoun in an extract where Pliny compares a plant with a pepper-like fruit (called oliva Indiae) to juniper (iunipiris nostris similes) implies that it was common in the Mediterranean Basin, cf. PlinY, Naturalis historia, XII, 26, 1-3. On the juniper in the Mediterranean, cf. A. Dalby, Food..., p. 187; M. Heilmeyer, Ancient Herbs, London 2007, p. 62.
} 
juniper was, at that time, perceived as useful in the treatment of hysteria and other women's diseases ${ }^{110}$.

There are strong indications that the sweet flag mentioned by Dioscorides was a pricey ingredient. Naturally, he was not referring to today's ubiquitous European variety, since it was not brought to the region until sometime between the Middle Ages and the $16^{\text {th }}$ century ${ }^{111}$, but he clearly meant the type imported from India, which he noted down while compiling a description of the plant ${ }^{112}$. In medicine, sweet flag was used in cathartic therapies and to cure women's diseases ${ }^{113}$.

Saffron was also accurately characterised by Dioscorides, who devoted a great deal of attention to listing the locations of its production ${ }^{114}$. Even though these were within the area of the Mediterranean Basin, and thus not far away from the Greco-Roman centres of civilisation, the prices of saffron were still exorbitant, which stemmed from that fact that the substance was extremely labour-consuming ${ }^{115}$ to obtain. Pliny also discussed saffron ${ }^{116}$, and the extract devoted to the places of its collection bears a resemblance to the characteristics presented in De materia medica. Another issue raised by Dioscorides was the problem of fake or adulterated saffron ${ }^{117}$, which unambiguously indicates its high pricing ${ }^{118}$, while Pliny mentions the fame it enjoyed as early as during the Trojan War ${ }^{119}$. When it comes to the application of saffron in therapies, from Dioscorides we learn

\footnotetext{
${ }^{110}$ Dioscorides, De materia medica, I, 75, 1, 8-10.

${ }^{111}$ H. Imam, Z. Riaz, M. Azhar, G. Sofi, A. Hussain, Sweet Flag (Acorus calamus Linn.): An Incredible Medicinal Herb, IJGP 7, 2013, p. 289.

${ }_{112}$ Dioscorides, De materia medica, I, 18, 1, 1-12. Calamus is also discussed by Pliny the Elder (Naturalis historia, XII, 48, 104-106) and GALEN (De simplicium medicamentorum temperamentis ac facultatibus, 6, $15-7,9$, vol. XII). Analogical data can be found in treatises by the early Byzantine physicians, cf. Oribasius, Collectiones medicae, XI, $\kappa, 2,1-4$; AËtius of AmIDA, Iatricorum libri, I, 176, 1-8; Paul of Aegina, Epitome, VII, 3, 10, 25-31. On the plant, cf. J.-P. Brun, X. Fernandez, Parfums antiques. De l'archéologue au chimiste, Milano 2015, p. 143-145.

${ }^{113}$ On purgation of the body through stimulation of urine production, cf. Dioscorides, De materia medica, I, 18, 1, 5. One of the ingredients of medicaments for female-specific diseases, cf. DIOSCORIDES, De materia medica, I, 18, 1, 7-8; I, 18, 1, 10-11.

${ }^{114}$ Dioscorides, De materia medica, I, 26, 1, $1-3,9$.

${ }^{115}$ Cf. A. Dalby, Dangerous Tastes. The Story of Spices, London 2002, p. 138. On the production of saffron in antiquity, cf. M. De Cleene, M.C. Lejeune, Compendium of Symbolic and Ritual Plants in Europe, vol. II, Herbs, Ghent 2003, p. 514.

${ }^{116}$ PLINY, Naturalis historia, XXI, 31, 1 - 34, 7.

${ }^{117}$ Dioscorides, De materia medica, I, 26, 2, 1-5.

${ }^{118}$ According to Edictum Diocletiani, a libra (327.45 grams) of Arabic saffron cost 2000 denarii (Edictum Diocletiani, 36, 60), a libra of Cilician saffron - 1000 denarii (Edictum Diocletiani, 36, 61), and a libra of African saffron - 600 denarii (Edictum Diocletiani, 36, 62).

${ }^{119}$ Pliny, Naturalis Historia, XXI, 34, 6-8. GALEN also took an interest in the pharmacological properties of saffron (cf. De simplicium medicamentorum temperamentis ac facultatibus, 48, 3-12, vol. XII). Analogical data can be found in treatises by the early Byzantine physicians, cf. OriBAsius, Collectiones medicae, XI, $\kappa, 39,1-10$; Aëtius of AmidA, Iatricorum libri, I, 231, 1-5; PAUl of AEGINA, Epitome, VII, 3, 10, 357-358.
} 
that it was used as a pharmaceutical agent in purgative procedures and to treat women's diseases ${ }^{120}$.

What indicates most chiefly the expensiveness of the sixth formula, however, is the use of myrrh, i.e. a resin which in antiquity become a symbol of high financial status. Let us commence by stating that myrrh was added to drinks not only for therapeutic purposes, as Pliny, on several occasions, mentions myrrh-aromatised wines in Naturalis historia ${ }^{121}$. While referring to a passage from Plautus' Persae, he recounts that, in the old days (apud priscos), these were the most valued wines (vina lautissima) ${ }^{122}$. On the basis of this note, we may conclude that they were prestigious and already had an established reputation at the times of the famous comic playwright, namely in the $2^{\text {nd }}$ century B.C. Within the same section, we can also find an excerpt from Plautus' Pdeudolus, in which he lists myrrh wine alongside such sweet drinks as passum, defrutum and water sweetened with honey ${ }^{123}$. On the basis of this extract, Pliny argues that wine was classified as a sweet alcoholic drink ${ }^{124}$.

Myrrh is a fragrant resin secreted by the genus Commiphora (Commiphora myrrha (Nees) Engl.), a plant native exclusively to the territory of the Arabian Peninsula, Ethiopia and Somalia ${ }^{125}$. The limited area where myrrh could be obtained,

\footnotetext{
${ }^{120}$ Dioscorides, De materia medica, I, 26, 1, 1- 3, 9 (purgation of the body through the stimulation of urine production - I, 26, 2, 6-7; additive to beverages administered for ailments of the uterus - I, 26, 3, 1-3). On saffron in medicine, cf. D. BAsker, M. NegBi, Uses of Saffron, EBot 37, 1983, p. 229-230.

${ }^{121}$ On myrrh-aromatised wines, cf. E. Koskenniemi, K. Nisulab, J. Topparic, Wine Mixed with Myrrh (Mark 15.23) and Crurifragium (John 19.31-32): Two Details of the Passion Narratives, JSNT 27, 2005, p. 379-386; P.E. Mcgovern, A. Mirzoian, G.R. Hall, O. Bar-Yosef, Ancient Egyptian Herbal Wines, PNAS 106, 2009, p. 7365.

${ }^{122}$ Pliny, Naturalis Historia, XIV, 92, 1-3.

${ }^{123}$ T. Maccius Plautus, Pseudolus, 741, [in:] Plauti comoediae, vol. II, ed. F. Leo, Berlin 1896. On the author and his output, cf. M. Fontaine, Between Two Paradigms: Plautus, [in:] The Oxford Handbook of Greek and Roman Comedy, ed. M. Fontaine, A.C. Scafuro, Oxford 2014, p. 516-537.

${ }^{124}$ PLINY, Naturalis historia, XIV, 93, 2-7. A remark from Columella's De re rustica suggests that the tradition of aromatising wine must with a blend of seasonings, including myrrh, was still alive in the $1^{\text {st }}$ century A.D., cf. Columella, De re rustica, XII, 20, 5.

${ }^{125}$ On the territories from which myrrh was imported to the Mediterranean, cf. G.W. van BEEK, Frankincense and Myrrh in Ancient South Arabia, JAOS 78, 1958, p. 143; IDEM, Frankincense and myrrh, BArch 23, 1960, p. 71-72; N. Groom, Frankincense and Myrrh. A Study of the Arabian Incense Trade, London 1981, p. 116-117; L. CAsson, Egypt, Africa, Arabia, and India: Patterns of Seaborne Trade in the First Century A.D., BASP 21, 1984, p. 42-43; R.D. TindeL, Zafar: Archaeology in the Land of Frankincense and Myrrh, Archaeo 37, 1984, p. 41; L. Costantini, L.B. Costantini, Le resine essenziali dall' Arabia meridionale. Incenso, mirra e balsamo, [in:] Aromatica. Essenze, profumi e spezie tra Oriente e Occidente. Roma, Museo Nazionale d'Arte Orientale, 7 maggio - 8 liuglio 2003, Roma 2003, p. 62-63; A. D’Hautcourt, Les Romains et le commerce des aromates dans l'Océan Indien, [in:] Parfums de l'Antiquité: la rose et l'encens en Méditerranée, ed. A. Verbanck-PiÉrard, N. MasSAR, D. Frère, Morlanwelz-Mariemont 2008, p. 318; S. Ben-Yehoshua, C. Borowitz, L.O. Hanuš,
} 
combined with the substantial distance from the centre of the Greco-Roman civilisation, translated into high prices, as for centuries myrrh was extremely difficult to acquire in the Mediterranean regions ${ }^{126}$. It also became the interest of Pliny ${ }^{127}$ and Dioscorides ${ }^{128}$, who devoted a substantial amount of attention to the substance. What is more, the details provided by both authors, to a greater extent, complement one another, which is also most likely the result of them both reading Niger's work ${ }^{129}$.

The largest amount of information regarding myrrh can be found in Naturalis historia, including specific price brackets related to various types of the resin. What stems from the account is that troglodytic myrrh enjoyed a special status ${ }^{130}$, as it was considered to be the most excellent of all the resins originating from the wild varieties of Commiphora plants ${ }^{131}$. It owed its exceptional reputation to its greasiness (pinguedo) ${ }^{132}$. Therefore, when interpreting the term used by the author, we may assume that it contained substances which - just like grease - were glossy, thus implying a high content of essential oils. And probably for that reason, a single grain of myrrh cost as much as sixteen and a half denarii ${ }^{133}$.

Frankincense, Myrrh, and Balm of Gilead: Ancient Spices of Southern Arabia and Judea, HRev 39, 2012, p. 7-9; G. Hardy, L. Totelin, Ancient..., p. 98; C. Singer, The Incense Kingdoms of Yemen: An Outline History of the South Arabian Incense Trade, [in:] Food for the Gods. New Light on the Ancient Incense Trade, ed. D.P.S. Peacock, D.L. Williams, Oxford 2007, p. 4-26; S. Bradley, Myrrh: Medical Knowledge from Arabia into Chinese Materia Medica, MS.AS 30, 2018, p. 883.

${ }^{126}$ On myrrh in Greco-Roman world, cf. F. DE Romanis, Tus e murra: aromi sudarabici nella Roma arcaica, [in:] Profumi d'Arabia. Atti del Convegno, ed. A. Avanzini, Roma 1997, p. 221-230; L.M.V. ToTelin, Hippocratic Recipes. Oral and Written Transmission of Pharmacological Knowledge in Fifthand Fourth-century Greece, Leiden 2009, p. 148-149; A. Dalby, Dangerous..., p. 118-120; S. BeN-Yehoshua, C. Borowitz, L.O. Hanuš, Frankincense..., p. 19; A. Giesecke, The Mythology of Plants. Botanical Lore from Ancient Greece and Rome, Los Angeles 2014, p. 85-90; J.-P. Brun, X. FerNANDeZ, Parfums..., p. 165-167; G. SQuillace, Le lacrime..., 132-135.

${ }^{127}$ PLInY, Naturalis historia, XII, 66, 1 - 71, 6.

${ }^{128}$ Dioscorides, De materia medica, I, 64, 1, 1 - 5, 9. GALEN also wrote on myrrh (De simplicium medicamentorum temperamentis ac facultatibus, 127, 3-16, vol. XII). Analogical data can be found in treatises by the early Byzantine physicians, cf. Oribasius, Collectiones medicae, XII, $\sigma, 35,1-22$; Aëtius of Amida, Iatricorum libri, I, 370, 1-7; Paul of Aegina, Epitome, VII, 3, 18, 127-132.

${ }^{129}$ Due to its multithreading, the issue of the relation between the two extracts cannot be the subject of divagations in this article. Therefore, we take the liberty of presenting only one argument, i.e. the fact that Pliny mentions Sextius Niger as one of the authors he read while compiling Book XII, cf. Pliny, Naturalis historia, I, 12b, 5.

${ }^{130}$ It was also greatly valued by Diosconides, cf. De materia medica, I, 64, 1, 7.

${ }^{131}$ Pliny, Naturalis historia, XII, 69, 1. The description of troglodytic myrrh, cf. Pliny, Naturalis historia, XII, 69, 7-8; Diosconides, De materia medica, I, 64, 1, 7-9. Both accounts differ slightly, which allows us to presume that either Dioscorides had the opportunity to see fresh troglodytic myrrh, as compared to the myrrh seen by Pliny, or he used the narrative of somebody who had seen such a substance.

${ }^{132}$ Pliny, Naturalis historia, XII, 69, 7.

${ }^{133}$ PlinY, Naturalis historia, XII, 70, 8. 
Although troglodytic myrrh was considered exceptionally aromatic, the noblest

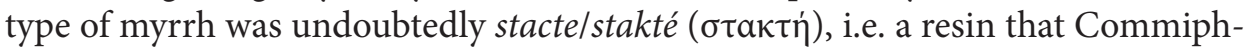
ora plants secreted naturally ${ }^{134}$. Pliny accounts that its prices ranged from three to fifty denarii per pound ${ }^{135}$.

The other, less expensive varieties of myrrh still remained an extremely pricey commodity for the average inhabitant of the Mediterranean world, and thus, for the product from Eritrea (also named 'Arabic') one had to pay sixteen denarii, then twelve denarii for the so-called odoraria, and one denarius less for the resin obtained from cultivated plants ${ }^{136}$.

From the encyclopaedist's account, we learn that myrrh was transported to Rome in leather sacks. Despite the long period of time between its harvest and sale, it would maintain its peculiar aroma and shine, which would allow perfume makers to distinguish good-quality myrrh from other more exotic products ${ }^{137}$. This information is of extra value for modern researchers, since it lets us imagine the conditions of the resin trade at that time. Moreover, the data preserved in the analysed source extract also indicates directly that recipients, including those aiming to produce the helleborites wine, could evaluate its quality by tasting and crumbling it prior to closing the deal ${ }^{138}$. This way, not only could they select the commodity of an appropriate quality, but they could also protect themselves against purchasing an adulterated resin, since - as we learn from the scrutinised source texts - it was common for wholesalers to commit unfair commercial practices, most likely in order to increase their profit margin. Thus, we can, for instance, read about a cheaper resin called cummi/kómmi (кó $\mu \mu$ ) being sold as myrrh ${ }^{139}$. And yet an experienced buyer, familiar with such properties as the taste and consistency that differentiated myrrh from other substances of that kind, could easily detect the fraud ${ }^{140}$. This, however, is another premise indicating the high prices of myrrh, the falsifying of which would have otherwise been unprofitable.

\footnotetext{
${ }^{134}$ Pliny, Naturalis historia, XII, 68, 2-3. On the substance, cf. R.O. Steuer, Myrrhe und Stakte, Wien 1933, passim; A. Lucas, Notes on Myrrh and Stacte, JEA 23, 1937, p. 27-33; L. MANniche, Sacred Luxuries. Fragrance, Aromatherapy, and Cosmetics in Ancient Egypt, Ithaca 1999, p. 29-30.

${ }^{135}$ PLINY, Naturalis historia, XII, 70, 6.

${ }^{136}$ Pliny, Naturalis historia, XII, 70, 7 - 71, 1. On the gradation of various species of myrrh, cf. PlinY, Naturalis historia, XII, 68, $1-70$, 5. The gradation of various species of myrrh, including their typical properties, compiled by Dioscorides, cf. De materia medica, I, 64, 1, 5-3, 5. Myrrh remained an extremely expensive commodity in the early $4^{\text {th }}$ century A.D. According to The Edict on Maximum Prices by Diocletian, a libra of oil made from stakté cost 600 denarii (Edictum Diocletiani, 36, 87), and a libra of troglodytic myrrh - 400 denarii (Edictum Diocletiani, 36, 104).

${ }^{137}$ PlinY, Naturalis historia, XII, 68, 6-9.

${ }^{138}$ On the properties of high-quality myrrh, which can be recognised after it has been crumbled or tasted, cf. Pliny, Naturalis historia, XII, 70, 1-4; Dioscorides, De materia medica, I, 64, 3, 1-4.

${ }_{139}$ Pliny, Naturalis historia, XII, 71, 1-3; Dioscorides, De materia medica, I, 64, 2, 8. The said resin is obtained from the tree of Acacia arabica (Lam.) Willd.

${ }^{140}$ PLINY, Naturalis historia, XII, 71, 3-4.
} 
Therefore, we conclude that myrrh was an ingredient of expensive and exclusive medicines, which - to a certain extent - explains why it was only used in two out of the seven formulas. We can also assume, however, that not only was it added to emphasise the financial standing of the patient and to give the medicament an attractive aroma, but also because it was believed to have a curative effect, justified from a therapeutic point of view. In De materia medica, we can read that the resin had some properties that were found useful in gynaecology (including abortifacient effects) ${ }^{141}$, various diseases of the respiratory $\operatorname{tract}^{142}$ (including such conditions as a runny nose $\mathrm{e}^{143}$ and cough ${ }^{144}$ ), and indigestion ${ }^{145}$.

Having proven that myrrh was a luxurious commodity in the Greco-Roman world, we shall now return to the composition of Dioscorides' lecture on helleboritai and focus on the middle formulas within both groups.

Let us begin with the second recipe and notice that the medicament in question was administered in the circumstances which we can interpret as a visit to a bathhouse. Although these places were a common sight in the Greco-Roman world of the $1^{\text {st }}$ century A.D., for the patient to be able to frequent them, they had to be located within a walking distance from his home. What is more, the sick had to have enough leisure time to use them. Therefore, the treatment was aimed neither at people whose days were filled with professional duties and errands, nor at the inhabitants of remote rural areas, located far away from urban centres, where such facilities could usually be found ${ }^{146}$. As a result, we may dare to conclude that the second formula for helleborites within the purgative class was targeted at city dwellers who were wealthy enough to visit a bath-house.

On the other hand, there is no clear indication of the financial status of the target female patients of the fifth recipe. We would, however, like to draw the reader's

\footnotetext{
${ }^{141}$ Dioscorides, De materia medica, I, 64, 3, 6-9.

${ }^{142}$ Dioscorides, De materia medica, I, 64, 3, 9-11; I, 64, 4, 3-4; I, 64, 5, 4-5.

${ }^{143}$ Dioscorides, De materia medica, I, 64, 5, 4-5 (runny nose).

${ }^{144}$ Dioscorides, De materia medica, I, 64, 3, 9-11 (cough).

${ }^{145}$ Dioscorides, De materia medica, I, 64, 3, 6-7; I, 64, 3, $11-4,1$. On the use of myrrh in ancient medical procedures, cf. M. Dayagi-Mendels, Perfumes and Cosmetics in the Ancient World, Jerusalem 1989, p. 106, 116; G. HadAs, The Balsam "Afarsemon" and Ein Gedi during the Roman-Byzantine Period, RB 114, 2007, p. 165; E. Lev, Z. Amar, Practical..., p. 221-223; K. Olson, Cosmetics in Roman Antiquity: Substance, Remedy, Poison, CW 102, 2009, p. 307; L.M.V. Totelin, Hippocratic..., p. 70 , 120, 129-131, 191, 262; L. Bodiou, L’huile et le corps médical. Usages de l'huile dans la pharmacopée des médecins hippocratiques, [in:] Les huiles parfumées en Méditerranée occidentale et en Gaule: VIII ${ }^{e}$ s. av.-VIII s. apr. J.-C. Actes du colloque organisé par l'université de Bretagne Sud et l'université de La Rochelle dans le cadre du programme de recherche Perhamo de l'Agence Nationale de la Recherche. Ce colloque s'est tenu à Rome (École française de Rome) du 16 au 18 novembre 2009, ed. D. Frère, L. HuGOT, Rennes 2012, p. 226; S. Ben-Yehoshua, L.O. Hanuš, Apharsemon, Myrrh and Olibanum: Ancient Medical Plants, [in:] Medicinal and Aromatic Plants of the Middle-East, ed. Z. YAnIv, N. DudAI, New York 2014, p. 111, 118-120; A. Giesecke, The Mythology..., p. 86-87; G. SQuillace, I balsami..., p. 94, 156, 158-159, 167, 169; Z. RzEŹnicKA, Mirra..., p. 53-65.

${ }^{146}$ G.G. FAGAN, Bathing in Public in the Roman World, Ann Arbor 1999, p. 205.
} 
attention to the fact that the preparation of the medicament was a very time-consuming process, since it could only be declared useable after six months. Therefore, when prepared at home, it could only be used by sexually active women in longer relationships, and most likely, not by primiparas, but those who were mothers to more than one child. Only then could they plan a long-term activity related to the preparation of this type of wine, and then use it to abort another foetus if they did not wish to have more children. And since the formula did not require them to use any imported ingredients, the medicament could be produced at a low cost, so it was aimed at women of low or lower than average financial status. Meanwhile, wealthy women who, regardless of their reasons, wished to end a pregnancy, could afford an abortifacient wine, which was not only more effective, but also guaranteed a desired aroma and taste, e.g. the beverage made in accordance with the sixth formula. And if this was the case, we may conclude that the wine from the fifth recipe was most commonly made due to economic reasons, i.e. the inability to support an excessive number of children without a noticeable decrease in the family's standard of living.

Thus, the sixth recipe should be interpreted as a medicament for women from wealthy families. Not only does it include expensive ingredients (e.g., saffron, sweet flag, and - above all - myrrh), but also their properties imply that the author of the formula wished to produce wine that smelled lovely and tasted luxurious, i.e. sweet. Therefore, it was produced from wine must obtained from raisins, which guaranteed a substantial sugar content that would most likely remain high even after a forty-day preparation period. Let us also add that, as accounted by Polybius, sweet passum was wine addressed specifically to women ${ }^{147}$, which means that its sweetness was not only to indicate the level of luxury, but also to reflect the customs and traditions of the Roman civilisation. Ipso facto, it signalled the gender of the patients for whom the medicament was composed ${ }^{148}$.

The analysis of the ingredients necessary to prepare the described alcoholic beverage allows us to make a supposition regarding another of its physical properties. Namely, the presence of saffron, which implies that it might have been added to emphasise the colour of the wine. And this was only possible if the wine was white or yellow by nature, and the hue became more intense in the course of ageing ${ }^{149}$. If our assumption is correct, we should also pay attention to the pharmacological properties of such beverage, as entrenched in Greek healthcare. The author of De diaeta in morbs acutis ${ }^{150}$, and then also Dioscorides ${ }^{151}$ and Galen ${ }^{152}$, considered

\footnotetext{
${ }^{147}$ Athenaeus of Naucratis, Deipnosophistae, X, 440e-f (56, 13-15 Kaibel).

${ }^{148}$ However, in general, Roman women were not supposed to drink wine, cf. B.F. RusselL, Wine, Women, and the Polis: Gender and the Formation of the City-state in Archaic Rome, GR 50, 2003, p. 77-84.

${ }^{149}$ This effect was unnoticeable in red or black wines.

${ }^{150}$ De diaeta in morbis acutis, 14, 3-16.

${ }^{151}$ Especially, cf. Dioscorides, De materia medica, V, 6, 11, 1-2.

${ }^{152}$ For instance - Galen, De alimentorum facultatibus, 744, 14 - 745, 3, vol. VI.
} 
yellow, sweet, and not excessively thick wines to offer the best therapeutic values. Taking this aspect of the formula into account, we may assume that when the sixth recipe was created, no effort was spared to ensure that the wine constituting the base of the medicament should be sweet, and also a good-quality product, from the perspective of medical theory. And this effort brings to mind fastidious recipients, i.e. upper-class women.

An argument that supports the latter supposition is the fact that the medicament was not only an agent aimed at terminating a pregnancy, but it was also used to address the consequences of miscarriages and hysteria. This versatile effectiveness may suggest that for the women who used it, abortion was not the only, but one of many reasons to do so. And if this was the case, one must add that the medicament was most likely administered on moral or family-based grounds, since upper-class women were not afflicted by the basic economic constraints typically faced by the poor.

Having concluded the analysis of the helleboritai catalogue, let us proceed to the medication for a runny nose, cough, indigestion, bloating, and excessive humidity within the stomach. Its formula contains two ingredients imported from remote locations (i.e. myrrh and pepper ${ }^{153}$ ), and one ingredient, namely iris, which was a plant native to the Mediterranean region. From the description in De materia medica, we learn that the latter originated from Illyria, Macedonia and Libya ${ }^{154}$, and because of its pleasant scent ${ }^{155}$, it was customarily used as an aromatising agent, and thus it was an ingredient of numerous perfumes, for instance, the oil called írinon ('ipıvov) ${ }^{156}$. Traditionally, it was also added to therapeutic wines ${ }^{157}$, and its properties facilitated healing of the upper respiratory $\operatorname{tract}^{158}$ and gastric disorders ${ }^{159}$.

${ }^{153}$ Dioscorides states that this seasoning was exported from India, cf. De materia medica, II, 159, 1,1 . He presented a great amount of data on pepper (including its white variant) and described its pharmacological properties, cf. Dioscorides, De materia medica, II, 159, 1, 1 - 4, 8. Pepper was also discussed by Pliny the Elder (Naturalis historia, XII, 26, 1 - 29,13) and Galen (De simplicium medicamentorum temperamentis ac facultatibus, 97, 7-16, vol. XII). Analogical data can be found in treatises by the early Byzantine physicians, cf. Oribasius, Collectiones medicae, XII, $\pi, 7,1-12$; AËtius of Amida, Iatricorum libri, I, 316, 1-5; PAul of Aegina, Epitome, VII, 3, 16, 27-31. On the spice, cf. A. DALBY, Dangerous..., p. 88-94; M.A. Совв, The Reception and Consumption of Eastern Goods in Roman Society, GR 60, 2013, p. 140-142; IDEM, Black Pepper Consumption in the Roman Empire, JESHO 61, 2018, p. 519-559.

${ }^{154}$ Dioscorides, De materia medica, I, 1, 1, 1 - 3, 5. Cf. Theophrastus, Enquiry into Plants and Minor Works on Odours and Weather Signs with an English Translation in Two Volumes, IX, 7, 4, 1-10, vol. II, trans. A. Hort, London 1916 (cetera: Theophrastus, Historia plantarum).

${ }^{155}$ Dioscorides emphasised this property three times, cf. De materia medica, I, 1, 1, 5; I, 1, 1, 9; I, 1, 1, 13. ${ }^{156}$ Dioscorides, De materia medica, I, 56, 1, 1 - 4, 6. On the plant, cf. M. Heilmeyer, Ancient..., p. 60; A. Giesecke, The Mythology ..., p. 59-65; J.-P. Brun, X. Fernandez, Parfums..., p. 161-163.

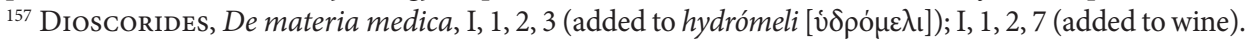
${ }^{158}$ Dioscorides, De materia medica, I, 1, 1, 10 (runny nose); I, 1, 2, 2 (cough).

${ }^{159}$ Dioscorides clearly states that it had a warming effect, thus accelerating digestion. Moreover, it would also have had diluting properties, i.e. it facilitated the absorption of products that generated 
Meanwhile, white pepper belonged to the class of goods imported from faraway India, which automatically made it expensive ${ }^{160}$ and unattainable to the poor. Despite its exorbitant price, it was frequently used in pharmacology, as confirmed, for instance, by its medical characteristics within De materia medica ${ }^{161}$, where we learn, inter alia, about the effectiveness of aromatic grains in treating diseases of the respiratory tract ${ }^{162}$ and the digestive system ${ }^{163}$.

The last ingredient of the beverage, i.e. dill, is by no means as sophisticated, common since antiquity both in the Mediterranean world and northern Europe, which makes it inexpensive ${ }^{164}$. Ancient physicians classified it as an effective constituent of medicaments facilitating digestion ${ }^{165}$.

Thus, a tally of the aromatic ingredients imported to Italia (three) collated with more common components (one) leads us to the conclusion that the medicament was not meant for all the sick, but only for people who could afford to pay the appropriate price. This thesis is additionally supported by another premise, namely a recommendation that the drink should be served after a walk, which implies that the patient had enough leisure time to allow them for such otium.

No particular type of wine was recommended within the analysed formula, which makes us presume that its brand was not of cardinal importance. On the other hand, it was mature, yellow wines with perceptible sweetness that were most effective in curing the ailments of the respiratory tract and the digestive system, which was not only mentioned by Dioscorides ${ }^{166}$, but also by Galen, who referred to the authority and expertise of his master, Hippocrates ${ }^{167}$. These wines would also be sold at the highest prices (as opposed to darker wines characterised by higher

thick juices. Finally, it also impacted the effective removal of thick juices and bile from the body, cf. Dioscorides, De materia medica, I, 1, 2, 1-4.

${ }^{160}$ According to The Edict on Maximum Prices by Diocletian, a pondus of pepper cost 800 denarii (Edictum Diocletiani, 36, 114).

${ }^{161}$ Dioscorides, De materia medica, II, 159, 1, $1-4,8$.

${ }^{162}$ Dioscorides, De materia medica, II, 159, 3, 5-9.

${ }^{163}$ Dioscorides, De materia medica, II, 159, 3, 10 - 4, 1.

${ }^{164}$ On dill in the Mediterranean, cf. A. Dalby, Food..., p. 117; M. Heilmeyer, Ancient..., p. 46.

${ }^{165}$ Dioscorides, De materia medica, III, 58, 1, 1-7 (as an ingredient of the medicine administered for digestive disorders - III, 58, 1, 1-2). The properties of dill were also discussed by GALEN, cf. De simplicium medicamentorum temperamentis ac facultatibus, 832, 1-18, vol. XI. The physician of Pergamon describes it as a substance with a warming (Grade 2 or 3 ) and drying (Grade 2 or 3 ) effect, important whenever a cough was caused by an excessive production of phlegm (GALEN, De simplicium medicamentorum temperamentis ac facultatibus, 832, 1-4, vol. XI), and as a substance that facilitates the digestion of raw and undigested juices that generated the production of gases (GALEN, De simplicium medicamentorum temperamentis ac facultatibus, 832, 6-7, vol. XI). Oil made from dill as a substance with an analogical effect, cf. GALEN, De simplicium medicamentorum temperamentis ac facultatibus, $832,7-14$, vol. XI).

${ }^{166}$ See, in particular, the information provided in the general description of wine - Dioscorides, De materia medica, V, 6, 11, 1-2.

${ }^{167}$ Galen, De placitis Hippocratis et Platonis, IX, 6, 38, 1 - 40, 1. 
acidity $\left.{ }^{168}\right)$. Since such beverages were usually classified as branded, perhaps the

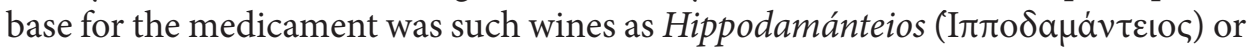

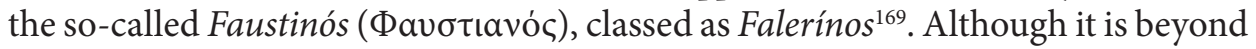
us to support this supposition with sufficient argumentation from source texts, we believe that the medicament was more likely meant for those who could afford to purchase Falerinos, rather than for those who had no choice but to drink lora ${ }^{170}$.

\section{Conclusions}

The analysis of the aforementioned formulas allows us to draw more and less detailed conclusions. Let us begin, however, with a more general one. Medical sources are more than just written material to provide us with information on the history of medicine, since they also contain data that enables us to learn a little more about society, and in particular, about its economic differences. Therefore, the division of patients according to their financial status translates into the different ingredients that are used to prepare a given medicament and various recommendations regarding the conditions of its administration. The study of recipes proves that the medical theory and practice presented by Dioscorides had to take into account this economic reality. Thus, the physician would choose different treatments for the poor and the rich, who could afford to purchase more expensive ingredients, and that is why his selection of formulas for purgative and abortifacient wines was based on financial status.

The preserved medical literature indicates that an analogical approach to constructing formulas and a similar medical practice were not exclusive to Dioscorides, which is perfectly illustrated by a story told by Galen in De compositione medicamentorum per gener ${ }^{171}$. In one of the passages, he describes his encounter with a wealthy man who took an interest in medicine and unsuccessfully tried to cure one of his servants who probably had some kind of a cancerous change on his skin. Eventually, the man turned to Galen, and once the physician healed the servant, the man asked him for a recipe of the medicament he had used ${ }^{172}$. Having found out, however, that it contained relatively cheap ingredients, the man considered the medicine as unworthy of his interest and refused to acknowledge the formula. The situation repeated when the same man, having ineffectively

\footnotetext{
${ }^{168}$ GALEN, De victu attenuante, 100, 1 - 101, 1.

${ }^{169}$ GALEN, De rebus boni malique suci, 801, 9-11, vol. VI.

${ }^{170}$ Low-end wines were produced from pomace.

${ }^{171}$ Galeni de compositione medicamentorum per genera libri VII, 635, 16 - 640, 12, [in:] Claudii Galeni opera omnia, vol. XIII, ed. C.G. KüHN, Lipsiae 1827 (cetera: GALEN, De compositione medicamentorum per genera).

${ }^{172}$ N.B., he thought that all changes of that type could be cured with one medicament, which - as suggested by Galen - irrefutably indicated his incompetence in the field of medicine, cf. GaLEN, De compositione medicamentorum per genera, 636, 11-14, vol. XIII.
} 
attempted to cure another servant suffering from a lesion to the cartilaginous tissues in the ear, sent the boy to Galen who was able to help him. This time, the man also asked the physician about the formula for the used medication, and once more, learning about its rather unsophisticated composition, he rejected it. Faced with such an attitude, Galen provided the wealthy man with medical recipes that satisfied his pursuit of luxury in the realm of medicine. From this account, we learn that the physician offered at least several formulas to the Roman ${ }^{173}$, the first of which - as will be emphasised here for the sake of exemplification - consisted of cinnamon, Cretan dittany ${ }^{174}$, cat thyme (Teucrium marum L.) and marjoram. The author admitted that the latter was included only because he knew it was not commonly available in Rome, and thus was also very expensive ${ }^{175}$. For our deliberations, it is important to bear in mind that one variant of the medicament was also enriched with myrrh oil ${ }^{176}$.

As can be concluded from the above story, for some patients a treatment was not a mere process of restoring good health, but also a way of satisfying their need to display their social status, which greatly depended on their financial situation ${ }^{177}$. Meanwhile, the material provided by Dioscorides leads us to conclude that the same way of reasoning even affected a decision to end a pregnancy, and the formulas he presents cast more light on the causes that pushed women in antiquity to make such a decision. On the other hand, both the catalogue of helleboritai within De materia medica, and the story told by Galen suggest neither refused to treat representatives of lower social classes, as is evidenced by the layout of formulas within the class of helleboritai wines, which opens with less complex and expensive medications, only to be followed by formulaic modifications aimed at satisfying the needs of more opulent recipients. This is also confirmed by the quoted story from De compositione medicamentorum per genera, where Galen emphasises how cheap the ingredients he commonly used were and how difficult it was for the

\footnotetext{
${ }^{173}$ GALEN, De compositione medicamentorum per genera, 637, 18 - 638, 1, vol. XIII.

${ }^{174}$ Origanum dictamnus $\mathrm{L}$.

${ }^{175}$ GALEN assured the reader that - from the perspective of the medical art - it was tried and tested, i.e. effective, cf. De compositione medicamentorum per genera, 639, 6-7, vol. XIII. The said formula, cf. GALEN, De compositione medicamentorum per genera, 638, 7 - 639, 6, vol. XIII.

${ }^{176}$ Cf. GALEN, De compositione medicamentorum per genera, 639, 11-12, vol. XIII. Other variants of the medicament, cf. GALEN, De compositione medicamentorum per genera, 639, 7-10, vol. XIII; $639,10-11$, vol. XIII. In the same extract, the physician also discusses variations of the formula for the medicament, produced from expensive ingredients and applied to open wounds, cf. GALEN, De compositione medicamentorum per genera, 639, 12 - 640, 12, vol. XIII.

${ }^{177}$ The anecdote told by Galen was used in three articles (to illustrate an analogical thesis). Cf. M. Кокоszко, Z. Rzeźnicka, Malábathron ( $\mu \alpha \lambda \alpha \dot{\beta} \alpha \theta \rho o v)$. Kilka..., p. 11-14; M. Kокоszко, Nard (vó $\rho \delta o c ;$ Nardostachys jatamansi [D. Don] DC) w wybranych źródłach greckich antyku i Bizancjum, [in:] Lek roślinny, vol. VI, Rośliny w lecznictwie, $w$ środowisku naturalnym i krajobrazie kulturowym, ed. B. PŁonka-Syroka, A. Syroka, Wrocław 2017, p. 37-39; M. Kokoszko, Z. Rzeźnicka, Malabathron ( $\mu \alpha \lambda \dot{\alpha} \beta \alpha \theta \rho o v)$ in Ancient..., p. 585-587.
} 
affluent man to accept. Thus, medicine did not merely aspire to address the needs of the financial elite, but it also took into consideration the necessity to serve society as a whole.

Also, worth noticing is the fact that the exclusiveness of the aforementioned formulas is sensorially justified and stems from their exceptional smell and sweet taste. When it comes to the former, it is relatively difficult to define. By and large, we believe that it could be described as having a unique aromaticity unlike one which is common and easily attainable, since it was usually the property of substances that were exotic or difficult to produce in large volumes. The exotic ones included sweet flag ${ }^{178}$, iris ${ }^{179}$, camel grass ${ }^{180}$, a plant called stáchys ${ }^{181}$, and naturally, myrrh ${ }^{182}$, while saffron represents the second category within the analysed formulas ${ }^{183}$.

Since the author of De materia medica, at the very beginning of his catalogue of therapeutic wines ${ }^{184}$, declared that the list may also be of interest to enthusiasts of medicine, we can imagine that Dioscorides did not write only with professionals in mind, but he also addressed his writings to amateurs attempting to cure themselves and others. This tendency for self-healing indicates that medical services were costly. On the other hand, medical knowledge must have plainly been fashionable, which is, for instance, confirmed by the fact that, in his Naturalis historia, Pliny derives a great amount of information from such medical works as the treatise by Sextius Niger. Another example of such amateur practitioners of medicine was also the wealthy man depicted in Galen's anecdote from De compositione medicamentorum per genera, as not only did he collect formulas, but he

\footnotetext{
${ }^{178}$ For instance, Dioscorides, De materia medica, I, 18, 1, 12. Sweet flag as a plant used in ancient perfume making, cf. R. Touzé, Les matières perfumières employées dans la confection des hulles, onguents et pouderes parfumée en Grèce ancienne, [in:] Parfums et odeurs dans l'antiquité, ed. L. BoDIOU, D. Frère, V. MeHL, Rennes 2009, p. 48-49.

${ }^{179}$ For instance, Dioscorides, De materia medica, I, 1, 1, 9. Iris as a plant used in ancient perfume making, cf. I. Erard-Cerceau, Végétaux..., p. 269; J.-P. Brun, X. Fernandez, Parfums..., p. 219-223.

${ }^{180}$ For instance, Theophrastus, Historia plantarum, IX, 7, 1, $12-2$, 3; IX, 7, 3, 4. Camel grass as a plant used in ancient perfume making, cf. I. ERARD-Cerceau, Végétaux..., p. 268.

${ }^{181}$ Dioscorides, De materia medica, III, 106, 1, 2.

${ }^{182}$ Theophrastus, Historia plantarum, IX, 7, 3, 4. Myrrh as a plant used in ancient perfume making, cf. P. Virgill, Culto della belleza e della seduzione, [in:] Bellezza e seduzione nella Roma imperiale, Roma, Palazzo dei Conservatori 11 giugno - 31 luglio 1990, Roma 1990, p. 43-44; J.-P. BRUn, The Production of Perfumes in Antiquity: the Cases of Delos and Paestum, AJA 104, 2000, p. 281; R. TouzÉ, Les matières..., p. 48-53; M. D’AcunTo, I profumi nella Grecia alto-arcaica: produzione, commercio, comportamenti sociali, [in:] I profumi nelle società antiche. Produzione, commercio, usi, valori simbolici, ed. A. Carannante, M. D’Acunto, Salerno 2012, p. 217-218.

${ }_{183}$ Theophrastus, Historia plantarum, IX, 7, 3, 4. Saffron as a plant used in ancient perfume making, cf. J.-P. BRUn, The Production..., p. 281, 290, 298, 300; B. Nicolas, Le vocabulaire de la parfumiere ancienne, [in:] Parfums et odeurs..., p. 38-39.

${ }^{184}$ Dioscorides, De materia medica, V, 19, 3, 2.
} 
also sought to treat his own servants ${ }^{185}$. Please, note that his actions were a continuation of a long-standing tradition, which in Italia was noted by Cato the Elder as early as in the $2^{\text {nd }}$ century B.C. ${ }^{186}$

As demonstrated in our deliberations, plant-based additives to therapeutic wines were not selected randomly, but according to their usefulness in achieving a specific curative goal. Therefore, Dioscorides describes black false hellebore, lemongrass and stachys as substances possessing pharmacological properties that facilitate the purgation of the gastrointestinal system, while white false hellebore, saffron, sweet flag and juniper berries are said to be effective in ending pregnancies, and dill, iris and white pepper in therapies of the respiratory tract and the digestion system. Myrrh, which we nominated an indicator of a high financial status, possessed all these properties, according to Greek medical theory. Thus, ancient physicians worked on the basis of an internally coherent theory, which was grounded on logic developed over centuries of medical practice.

An example of such 'organisation' of knowledge is the work by Dioscorides, since - as we demonstrated in this study - the data preserved by the author is arranged following a purposefully constructed scheme. Although it is not certified before the $1^{\text {st }}$ century A.D., it does not mean that lost treatises from the earlier period are not responsible for shaping the method about which we learnt from De materia medica. Nevertheless, Dioscorides' output in that matter must have been exceptional: it deftly summarised everything that had been established prior to its compilation. Its virtues are confirmed by the fact that the treatise survived to influence subsequent generations, while earlier works had sunk into oblivion.

The analysed formulas for therapeutic wines also provide us with material allowing us to make several observations on the experts and works that Dioscorides referred to. While the general knowledge of wines in De materia medica originated, in all probability, from Perí hýles, there are no arguments that would enable us to attribute, beyond all doubt, the authorship of formulas within the catalogue of therapeutic wines to a specific person. As far as the first and fourth recipes are concerned, they are reworkings of various traditional folk formulas, which may as well have been written either by Dioscorides himself or by his predecessors. On the other hand, the formulas including exclusive additives were probably jotted down by Greek physicians, older than the scholar from Anazarbus. To our mind, they owe the form we know from De matera medica to Sextius Niger, since he was in the habit of including specific formulas for therapeutic wines, as evidenced by the examples of adýnamos and melitites wines discussed above. What is more, the inclusion of aromatised wines in Pliny's Naturalis historia ${ }^{187}$ implies that at least

\footnotetext{
${ }^{185}$ GALEN, De compositione medicamentorum per genera, 636, 9-10, vol. XIII.

${ }^{186}$ Cf. CAто, De agri cultura, 94, 1-2; 95, 1-2 (therapeutic wines with black false hellebore); 122; $123 ; 125 ; 126 ; 127,1-2 ; 156,1-7 ; 157,1-15 ; 158,1-2 ; 159$. Not only did Cato treat people, but also animals, for instance, cf. CATO, De agri cultura, 70, 1-2; 71.

${ }^{187}$ PuINY, Naturalis historia, XIV, 98, 1 - 114, 5.
} 
some of the recipes from De materia medica had been written down by Sextius Niger or borrowed from his masters, namely Asclepiades of Bithynia ${ }^{188}$ and Themison $^{189}$.

Since Niger is very likely to have been responsible not only for Dioscorides' knowledge of wines, but also his expertise in numerous aromatising additives, our deliberations are yet another contribution to an appropriate evaluation of Sextius Niger's share in shaping theoretical attitudes of ancient and Byzantine pharmacology. We fancy that his actual impact must have been much greater than the fame his figure enjoys today among experts in the history of medicine.

The results of our studies also allow us to remark briefly on a work which - although mentioned in this article - represents the medical output of the subsequent early Byzantine era, i.e. Book V of Collectiones medicae by Oribasius, where we find a recipe for one of the wines from the class of helleboritai ${ }^{190}$. This is, to some extent, a copy of the first formula, but with types of false hellebore specified as helléboros mélas, which is missing in the preserved work by Dioscorides. Since both types of hellebore were used for similar purposes, the variant from Collectiones medicae was either a legitimation of practice or a mistake made by Oribasius in the course of collecting data. The latter option is more probable because, as we specified above, Dioscorides had in mind white hellebore, and after all, he was a specialist in the realm of materia medica, while - for Oribasius - the knowledge derived from Dioscorides' treatise constituted just a fraction of the ancient output included within his exhaustive compilation.

The preserved material also proves that the science of wine and of its aromatising additives was not modified after the $1^{\text {st }}$ century A.D., which, in consequence, shows that medicine did not develop in that matter and chose to draw from the output of experts from the Byzantine period. Thus, it seems appropriate to suggest that later it was not deemed necessary to transform the foundations of pharmacology, because, on the one hand, a fully crystallised form of the theory already existed before the $1^{\text {st }}$ century, and, on the other, there was a lack of modifying factors, resulting from the invariability of the range of medicaments available to physicians. Therefore, there is every likelihood that Dioscorides, and later Oribasius, Aëtius of Amida, and Paul of Aegina duplicated opinions which were already considered classical, since any changes in the range of attainable wines and winemaking technologies (including their characteristics as therapeutic agents) were minor during the lifetime of the aforementioned authors. If this was the case, then the treatise by Dioscorides as well as other medical texts which contain teachings on wine are not only becoming source material for the history of medicine sensu stricto, but also important accounts of the ancient and early Byzantine economy, and particularly, grapevine cultivation and winemaking.

\footnotetext{
${ }^{188}$ PlINY, Naturalis historia, XXIII, 32, 1-3.

${ }^{189}$ PLINY, Naturalis historia, XIV, 114, 5 - 115, 1.

${ }^{190}$ Oribasius, Collectiones medicae, V, 25, 41, 1 - 43, 1.
} 


\section{Bibliography}

\section{Primary Sources}

Aetii Amideni libri medicinales I-VIII, ed. A. Olivieri, Lipsiae-Berolini 1935-1950.

Athenaei Naucratitae dipnosophistarum libri XV, vol. I-III, rec. G. KAIBEL, Lipsiae-Berolini 1887-1890.

C. Plini Secundi naturalis historiae libri XXXVII, vol. I-VI, ed. C. MAYноғF, Lipsiae 1875-1906.

De diaeta in morbis acutis, [in:] Oeuvres completes d'Hippocrate, vol. II, ed. É. LitTré, Paris 1840.

Edictum Diocletiani et Collegarum de pretiis rerum venalium, vol. I-II, ed. M. GIACCHERo, Genova 1974.

Galen, On the Doctrines of Hippocrates and Plato, ed. P.H. De Lacy, Berlin 1978.

Galeni de alimentorum facultatibus libri III, [in:] Claudii Galeni opera omnia, vol. VI, ed. C.G. KüHN, Lipsiae 1823.

Galeni de antodotis libri II, [in:] Claudi Galeni opera omnia, vol. XIV, ed. C.G. KüHN, Lipsiae 1827.

Galeni de compositione medicamentorum per genera libri VII, [in:] Claudii Galeni opera omnia, vol. XIII, ed. C.G. KüHN, Lipsiae 1827.

Galeni de compositione medicamentorum secundum locos libri X, [in:] Claudii Galeni opera omnia, vol. XII-XIII, ed. C.G. KüHN, Lipsiae 1826-1827.

Galeni de linguarum seu dictionum exoletarum Hippoctratis explicatio, [in:] Claudii Galeni opera omnia, vol. XIX, ed. C.G. KüHN, Lipsiae 1830.

Galeni de methodo medendi libri XIV, [in:] Claudii Galeni opera omnia, vol. X, ed. C.G. KüHN, Lipsiae 1825.

Galeni de rebus boni malique suci libellus, [in:] Claudii Galeni opera omnia, vol. VI, ed. C.G. KüHN, Lipsiae 1823.

Galeni de sanitate tuenda libri VI, [in:] Claudii Galeni opera omnia, vol. VI, ed. C.G. KüHN, Lipsiae 1823.

Galeni de simplicium medicamentorum temperamentis ac facultatibus libri XI, [in:] Claudii Galeni opera omnia, vol. XI-XII, ed. C.G. KüHN, Lipsiae 1826-1827.

Galeni de victu attenuante, ed. K. KALBFLEISCH, Leipzig-Berlin 1923.

Geoponica sive Cassiani Bassi Scholastici de re rustica eclogae, rec. H. BECKH, Lipsiae 1895.

Lucius Iunius Moderatus Columella, On Agriculture in Three Volumes, Books 10-12 and De arboribus, vol. III, trans. E.S. Forster, E.H. HefFner, London-Cambridge 1955.

M. Porci Catonis de agri cultura, rec. H. KeIL, Lipsiae 1895.

Oribasii collectionum medicarum reliquiae, vol. I-IV, ed. I. RAEDER, Lipsiae-Berolini 1928-1933.

Paulus Aegineta, vol. I-II, ed. I.L. Heiberg, Lipsiae-Berolini 1921-1924.

Pedanii Dioscuridis Anazarbei de materia medica libri V, vol. I-III, ed. M. Wellmann, Berolini 1906-1914.

T. Maccius Plautus, Pseudolus, [in:] Plauti comoediae, vol. II, ed. F. Leo, Berlin 1896.

Theophrastus, Enquiry into Plants and Minor Works on Odours and Weather Signs with an English Translation in Two Volumes, vol. II, trans. A. HorT, London 1916. 


\section{Secondary Literature}

Alcock J.P., Food in the Ancient World, Westport-London 2006.

Alessi R., Le vin dans les Épidémies d'Hippocrate, [in:] Vin et santé en Grèce Ancienne, Actes du Colloque organisé à l'Université de Rouen et à Paris (Université de Paris IV Sorbonne et ENS) par l'UPRESA 8062 du CNRS et l'URLLCA de l'Université de Rouen, 28-30 septembre 1998, ed. J. Jouanna, L. Villard, Athènes 2002, p. 105-112.

Anagnōstakēs Ē., Bvzantinos oinikos politismos. Wine Culture in Byzantium, Athēna /Athens 2008.

AnAGnōstakēs Ē., O Byzantinos oinikos politismos, [in:] Oivos: politismos kai koivōnia, ed. E. GramMatikopoulou, Athēna, p. 39-67.

Anagnostakis I., The Sweet Wine of Bithynia in the Byzantine Era, [in:] Of Vines and Wines. The Production and Consumption of Wine in Anatolian Civilizations through the Ages, ed. L. THys-ŞENOCAK, Leuven-Paris-Bristol 2017, p. 93-117.

ANDRÉ J., Lexique des termes de botanique en latin, Paris 1956.

ANDRÉ J., Le noms de plantes dans la Rome antique, Paris 1985.

Arnould D., Du bon usage du vin chez Homère et dans la poésie archaïque, [in:] Vin et santé en Grèce Ancienne, Actes du Colloque organisé à l'Université de Rouen et à Paris (Université de Paris IV Sorbonne et ENS) par l'UPRESA 8062 du CNRS et l'URLLCA de l'Université de Rouen, 28-30 septembre 1998, ed. J. Jouanna, L. Villard, Athènes 2002, p. 7-10.

BALdwin B., Athenaeus and His Work, "Acta Classica" 19, 1976, p. 21-42.

Baldwin B., The Career of Oribasius, "Acta Classica" 18, 1975, p. 85-97.

Bartol K., Atenajosa $z$ Naukratis ksiega win (Deipnosophistai 25f-40f), "Meander" 50, 1995, p. 215-226.

Basker D., Negbi M., Uses of Saffron, "Economic Botany" 37, 1983, p. 228-236.

BeAgon M., The Elder Pliny on the Human Animal. Natural History, Book 7, Oxford 2005.

Beagon M., Roman Nature. The Thought of Pliny the Elder, Oxford 1992.

BeEK G.W. van, Frankincense and Myrrh in Ancient South Arabia, "Journal of the American Oriental Society" 78, 1958, p. 141-152.

BeEk G.W. van, Frankincense and Myrrh, “The Biblical Archaeologist” 23, 1960, p. 69-95.

BÉGuIn D., Le vin médecin chez Galien, [in:] Vin et santé en Grèce Ancienne, Actes du Colloque organisé à l'Université de Rouen et à Paris (Université de Paris IV Sorbonne et ENS) par l'UPRESA 8062 du CNRS et l'URLLCA de l'Université de Rouen, 28-30 septembre 1998, ed. J. JouANNA, L. VILLARD, Athènes 2002, p. 141-154.

Ben-Yenoshua S., Hanuš L.O., Apharsemon, Myrrh and Olibanum: Ancient Medical Plants, [in:] Medicinal and Aromatic Plants of the Middle-East, ed. Z. Yaniv, N. DudaI, New York 2014, p. 67-150.

Ben-Yehoshua S., Borowitz C., Hanuš L.O., Frankincense, Myrrh, and Balm of Gilead: Ancient Spices of Southern Arabia and Judea, "Horticultural Reviews" 39, 2012, p. 1-76.

Bio I., Antyllos, [in:] Antike Medizin. Ein Lexikon, ed. K.-H. Leven, München 2005, col. 62-63.

Bodiou L., L'huile et le corps médical. Usages de l'huile dans la pharmacopée des médecins hippocratiques, [in:] Les huiles parfumées en Méditerranée occidentale et en Gaule: VIII' s. av.-VIII ${ }^{e}$ s. apr. J.-C. Actes du colloque organisé par l'université de Bretagne Sud et l'université de La Rochelle dans le cadre du programme de recherche Perhamo de l'Agence Nationale de la Recherche. Ce colloque 
s'est tenu à Rome (École française de Rome) du 16 au 18 novembre 2009, ed. D. Frère, L. Hugot, Rennes 2012, p. 221-229.

Boudon V., Un médecin oenophile: Galien et le vin de Falerne, [in:] Vin et santé en Grèce Ancienne, Actes du Colloque organisé à l'Université de Rouen et à Paris (Université de Paris IV Sorbonne et ENS) par l'UPRESA 8062 du CNRS et l'URLLCA de l'Université de Rouen, 28-30 septembre 1998, ed. J. Jouanna, L. Villard, Athènes 2002, p. 155-163.

Boulay T., Wine Appreciation in Ancient Greece, [in:] A Companion to Food in the Ancient World, ed. J. Wilkins, R. NADEAU, Chichester 2015, p. 273-282.

Bradley S., Myrrh: Medical Knowledge from Arabia into Chinese Materia Medica, "Medicina nei Secoli: Arte e Scienza" 30, 2018, p. 881-906.

Brock R., Wirtejs H., Athenaeus on Greek Wine, [in:] Athenaeus and His World. Reading Greek Culture in the Roman Empire, ed. D. BRAUnd, J. Wilkins, Exeter 2000, p. 455-465.

Brun J.-P., The Production of Perfumes in Antiquity: the Cases of Delos and Paestum, "American Journal of Archaeology" 104, 2000, p. 277-308.

Brun J.-P., Fernandez X., Parfums antiques. De l'archéologue au chimiste, Milano 2015.

Casson L., Egypt, Africa, Arabia, and India: Patterns of Seaborne Trade in the First Century A.D., "Bulletin of the American Society of Papyrologists" 21, 1984, p. 39-47.

Совв M., Black Pepper Consumption in the Roman Empire, "Journal of the Economic and Social History of the Orient" 61,2018 , p. 519-559.

Совв M.A., The Reception and Consumption of Eastern Goods in Roman Society, "Greece \& Rome" 60, 2013, p. 136-152.

Costantini L., Costantini L.B., Le resine essenziali dall' Arabia meridionale. Incenso, mirra e balsamo, [in:] Aromatica. Essenze, profumi e spezie tra Oriente e Occidente. Roma, Museo Nazionale d'Arte Orientale, 7 maggio - 8 liuglio 2003, Roma 2003, p. 59-63.

D’Acunto M., I profumi nella Grecia alto-arcaica: produzione, commercio, comportamenti sociali, [in:] I profumi nelle società antiche. Produzione, commercio, usi, valori simbolici, ed. A. CARANNANTE, M. D’Acunto, Salerno 2012, p. 191-233.

D’Hautcourt A., Les Romains et le commerce des aromates dans l'Océan Indien, [in:] Parfums de l'Antiquité: la rose et l'encens en Méditerranée, ed. A. Verbanck-Piérard, N. Massar, D. Frère, Morlanwelz-Mariemont 2008, p. 317-322.

Dalby A., Dangerous Tastes. The Story of Spices, London 2002.

Dalby A., Food in the Ancient World from A to Z, London-New York 2003.

Dalby A., Tastes of Byzantium. The Cuisine of a Legendary Empire, London 2010.

Dayagi-Mendels M., Perfumes and Cosmetics in the Ancient World, Jerusalem 1989.

De Cleene M., Lejeune M.C., Compendium of Symbolic and Ritual Plants in Europe, vol. II, Herbs, Ghent 2003.

de Romanis F., Tus e murra: aromi sudarabici nella Roma arcaica, [in:] Profumi d'Arabia. Atti del Convegno, ed. A. Avanzini, Roma 1997, p. 221-230.

Deichgräber K., Sextius Niger, [in:] Paulys Real-Encyclopädie der classischen Altertumswissenschaft, Supplementband V, Stuttgart 1931, col. 971-972.

Dickson K., Theōn of Alexandria (Med. II) (ca 300-500 CE), [in:] The Encyclopedia of Ancient Natural Scientists. The Greek Tradition and its Many Heirs, ed. P. Keyser, G.L. Irby-Massie, Milton Park-New York 2008, p. 795. 
do Sameiro Barroso M., The Hellebore, the Plant Beloved by the Greeks: the Reasons Behind a Myth, "Vesalius" 21, 2015, p. 30-37.

Donahue J.F., Culinary and Medicinal Uses of Wine and Olive Oil, [in:] A Companion to Science, Technology, and Medicine in Ancient Greece and Rome, vol. I-II, ed. G.L. Irby, Malden-OxfordChichester 2016, p. 605-617.

Erard-Cerceau I., Végétaux, parfums, et parfumeurs à l'époque mycénienne, "Studi Micenei ed Egeo-Anatolici" 28, 1990, p. 251-285.

Everett N., The Alphabet of Galen. Pharmacy from Antiquity to the Middle Ages. A Critical Edition of the Latin Text with English Translation and Commentary, Toronto 2012.

Fagan G.G., Bathing in Public in the Roman World, Ann Arbor 1999.

Flemming R., Galen's Imperial Order of Knowledge, [in:] Ordering Knowledge in the Roman Empire, ed. J. KöNig, T. Whitmarsh, Cambridge 2007, p. 241-277.

Fontaine M., Between Two Paradigms: Plautus, [in:] The Oxford Handbook of Greek and Roman Comedy, ed. M. Fontaine, A.C. Scafuro, Oxford 2014, p. 516-537.

Fraser H.D., The Influence of Greece on Science and Medicine, "The Scientific Monthly" 3, 1916, p. 51-65.

Gabriel R.A., Man and Wound in the Ancient World. A History of Military Medicine from Sumer to the Fall of Constantinople, Washington 2012.

Geōrgakopoulos K., Archaioi Ellēnes iatroi, Athēna 1998.

Giesecke A., The Mythology of Plants. Botanical Lore from Ancient Greece and Rome, Los Angeles 2014.

Grivetti L.E., Wine: the Food with Two Faces, [in:] The Origins and Ancient History of Wine, ed. P. Mcgovern, S.J. Flemming, S. Katz, Amsterdam 1996, p. 9-22.

Groom N., Frankincense and Myrrh. A Study of the Arabian Incense Trade, London 1981.

Gurunluoglu R., Gurunluoglu A., Paul of Aegina: Landmark in Surgical Progress, "World Journal of Surgery" 27, 2003, p. 18-25.

Hadas G., The Balsam "Afarsemon" and Ein Gedi during the Roman-Byzantine Period, "Revue biblique" 114, 2007, p. 161-173.

Hardy G., Totelin L., Ancient Botany, London-New York 2016.

Heilmeyer M., Ancient Herbs, London 2007.

Hunter R., Koukouzika D., Food in Greek Literature, [in:] A Companion to Food in the Ancient World, ed. J. Wilkins, R. NADEaU, Chichester 2015, p. 19-29.

Imam H., Riaz Z., Azhar M., Sofi G., Hussain A., Sweet Flag (Acorus calamus Linn.): An Incredible Medicinal Herb, "International Journal of Green Pharmacy" 7, 2013, p. 288-296.

Irby-Massie G.L., Andreas of Karustos (ca 250-217 BCE), [in:] The Encyclopedia of Ancient Natural Scientists. The Greek Tradition and its Many Heirs, ed. P. Keyser, G.L. Irby-Massie, Milton Park-New York 2008, p. 77-78.

Irby-Massie G.L., Keyser P.T., Greek Science of the Hellenistic Era. A Sourcebook, London-New York 2002.

Irwin M.E., Greek and Roman Botany, [in:] A Companion to Science, Technology, and Medicine in Ancient Greece and Rome, vol. I-II, ed. G.L. Irby, Malden-Oxford-Chichester 2016, p. $265-280$. 
JaCQUes J.-M., Krateuas (100-60 BCE), [in:] The Encyclopedia of Ancient Natural Scientists. The Greek Tradition and its Many Heirs, ed. P. Keyser, G.L. Irby-Massie, Milton Park-New York 2008, p. 491.

Jagusiak K., Кокоszко M., Życie i kariera Orybazjusza w świetle relacji źródłowych, "Przegląd Nauk Historycznych" 10, 2011, p. 5-21.

Jones-Lewis M., Pharmacy, [in:] A Companion to Science, Technology, and Medicine in Ancient Greece and Rome, vol. I-II, ed. G.L. IRBY, Malden-Oxford-Chichester 2016, p. 402-417.

Jouanna J., Le vin chez Arétée de Cappadoce, [in:] Vin et santé en Grèce Ancienne, Actes du Colloque organisé à l'Université de Rouen et à Paris (Université de Paris IV Sorbonne et ENS) par l'UPRESA 8062 du CNRS et l'URLLCA de l'Université de Rouen, 28-30 septembre 1998, ed. J. JouAnNA, L. Villard, Athènes 2002, p. 113-126.

Jouanna J., Le vin et la médecine dans la Grèce ancienne, "Revue des Études Grecques" 109, 1996, p. 410-434 (= J. Jounnna, Wine and Medicine in Ancient Greece, [in:] Greek Medicine from Hippocrates to Galen. Selected Papers, ed. P. van Der EijK, trans. N. Allies, Leiden-Boston 2012, p. 173-193).

Kalantzēs G., Tsiamēs K., Poulakou-Rempelakou E., Oreibasios kai Paulos Aiginētēs. Duo Byzantinoi iatroi, prōtoporoi stēv Plastikē Cheipourgikēe, "Archives of Hellenic Medicine / Apxeía

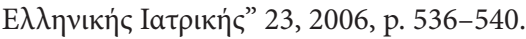

Кокозzко M., Enologia Dioskuridesa, czyli kilka uwag na temat leczniczego działania wina, [in:] Historia panaceum. Między marzeniem a oszustwem, ed. W. KorpalsKa, W. ŚlusarczyK, Bydgoszcz 2016, p. 49-62.

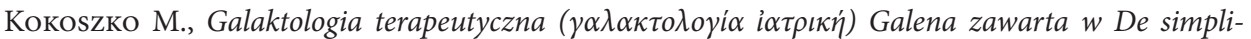
cium medicamentorum temperamentis ac facultatibus, "Przegląd Nauk Historycznych" 14, 2015, p. 5-23.

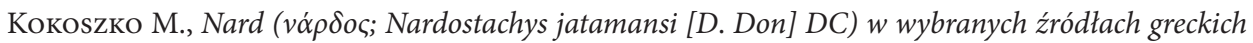
antyku i Bizancjum, [in:] Lek roślinny, vol. VI, Rośliny w lecznictwie, w środowisku naturalnym i krajobrazie kulturowym, ed. B. PŁonka-Syroka, A. Syroka, Wrocław 2017, p. 31-51.

Кокоszко M., Ryby i ich znaczenie w życiu codziennym ludzi późnego antyku i Bizancjum (IV-VII w.), Łódź 2005 [= Byzantina Lodziensia, 9].

Кокозzко M., Rzodkiew (Raphanus L) w wybranych źródłach antyku i Bizancjum, [in:] Lek rośliny, vol. IV, Produkty pochodzenia roślinnego w lecznictwie, dietetyce, kosmetyce, ekonomice i kulturze popularnej, ed. B. PŁonka-Syroka, A. Syroka, Wrocław 2015, p. 15-33.

Kокозzко M., Smaki Konstantynopola, [in:] Konstantynopol - Nowy Rzym. Miasto i ludzie w okresie wczesnobizantyńskim, ed. M.J. LeszKa, T. WolińsKa, Warszawa 2011, p. 471-575.

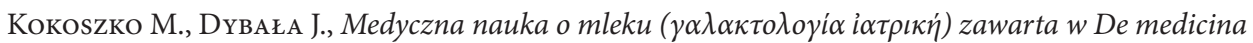
Celsusa, "Przegląd Nauk Historycznych" 15, 2016, p. 5-43.

Koкоszкo M., Dyваєa J., Milk in Medical Theory Extant in Celsus' De medicina, "Journal of Food Science and Engineering" 6, 2016, p. 267-279.

Кокоszкo M., Jagusiak K., Rzeźnicka Z., Cereals of Antiquity and Early Byzantine Times. Wheat and Barley in Medical Sources, trans. K. Wodarczyк, M. Zakrzewski, M. ZytKa, Łódź 2014 [= Byzantina Lodziensia, 20].

Koкоszкo M., Jagusiak K., RzeźNicka Z., Dietetyka i sztuka kulinarna antyku i wczesnego Bizancjum (II-VII w.), Część I, Zboża i produkty zbożowe w źródłach medycznych antyku i wczesnego Bizancjum, Łódź 2014 [= Byzantina Lodziensia, 16]. 
Koкoszko M., Jagusiak K., Rzeźnicka Z., Dybąa J., Pedanius Dioscorides' Remarks on Milk Properties, Quality and Processing Technology, "Journal of Archaeological Science: Reports" 19, 2018, p. 982-986.

Koкoszko M., Jagusiak K., Rzeźnicka Z., Dyba£a J., The Radish (Raphanus L.) in Selected Sources from Antiquity and the Byzantine Period, "Епохи" 26, 2018, p. 79-91.

Кокоszко M., RzeźNicka Z., Malabathron ( $\mu \alpha \lambda \dot{\alpha} \beta \alpha \theta \rho o v)$ in Ancient and Early Byzantine Medicine and Cuisine, "Medicina nei Secoli: Arte e Scienza" 30, 2018, p. 579-616.

Koкоszкo M., Rzeźnicka Z., Malábathron ( $\mu \alpha \lambda \dot{\alpha} \beta \alpha \theta \rho o v)$. Kilka uwag o roli Cinnamomum tamala w kuchni i medycynie antyku i Bizancjum w okresie pomiędzy I a VII wiekiem, "Przegląd Nauk Historycznych" 15, 2016, p. 5-42.

Koskenniemi E., Nisulab K., Topparic J., Wine Mixed with Myrrh (Mark 15.23) and Crurifragium (John 19.31-32): Two Details of the Passion Narratives, "Journal for the Study of the New Testament" 27, 2005, p. 379-391.

La Penna A., Immortale Falernum. Il vino di Marziale e dei poeti latini del suo tempo, "Maia" 51, 1999, p. 163-181.

La Penna A., Il vino di Orazio: nel modus e contro il modus, [in:] In vino veritas, ed. O. Murray, M. Tecuşan, Oxford 1995, p. 266-282.

Laurence R., Roman Passions. A History of Pleasure in Imperial Rome, London 2010.

Letts M., Rufus of Ephesus and the Patient's Perspective in Medicine, "British Journal for the History of Philosophy" 22, 2014, p. 996-1020.

Lev E., Amar Z., Practical Materia Medica of the Medieval Eastern Mediterranean according to the Cairo Genizah, Leiden-Boston 2008.

López Salvá M., Efectos patológicos del vino en el Corpus Hippocraticum, [in:] Le normal et le pathologique dans la Collection hippocratique, Actes $d u X^{\text {ème }}$ colloque international hippocratique, Nice, 6-8 octobre 1999, ed. A. Thivel, A. Zucker, Nice 2002, p. 523-537.

LuCAs A., Notes on Myrrh and Stacte, "Journal of Egyptian Archaeology" 23, 1937, p. 27-33.

Maieron M.A., On the Hellebore Trail an Anthropological Research into Madness, "Medicina Historica" 2, 2018, p. 5-18.

Manniche L., Sacred Luxuries. Fragrance, Aromatherapy, and Cosmetics in Ancient Egypt, Ithaca 1999.

Masullo R., Philagrios, [in:] Antike medizin. Ein Lexikon, ed. K.-H. Leven, München 2005, col. 693-694.

Mattern S.P., The Prince of Medicine. Galen in the Roman Empire, Oxford 2013.

McGovern P.E., Ancient Wine. The Search for the Origins of Viniculture, Princeton 2003.

McGovern P.E., Mirzoian A., Hall G.R., Bar-Yosef O., Ancient Egyptian Herbal Wines, "Proceedings of the National Academy of Sciences of the United States of America" 106, 2009, p. 7361-7366.

Micalella D., Vino e amore: Ippocrate, "Quaderni Urbinati di Cultura Classica" 24, 1977, p. 151-155.

Moravcsik J., Ancient and Modern Conceptions of Health and Medicine, "Journal of Medicine and Philosophy" 1, 1976, p. 337-348.

Nicolas B., Le vocabulaire de la parfumiere ancienne, [in:] Parfums et odeurs dans l'antiquité, ed. L. Bodiou, D. Frère, V. MeHL, Rennes 2009, p. 33-43.

Nutton V., Ancient Medicine, London-New York 2004. 
Olson K., Cosmetics in Roman Antiquity: Substance, Remedy, Poison, "The Classical World" 102, 2009, p. 291-310.

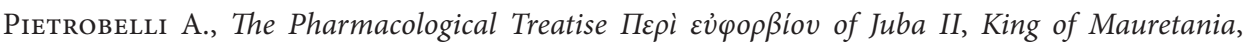
[in:] 'Greek' and 'Roman' in Latin Medical Texts. Studies in Cultural Change and Exchange in Ancient Medicine, ed. B. MaIre, Leiden-Boston 2014, p. 157-182.

Pormann P.E., Paulos of Aigina (ca 630-670 CE?), [in:] The Encyclopedia of Ancient Natural Scientists. The Greek Tradition and its Many Heirs, ed. P. Keyser, G.L. Irby-Massie, Milton ParkNew York 2008, p. 629.

Prioreschi P., A History of Medicine, vol. III, Roman Medicine, Omaha 1998.

Purcell N., Wine and Wealth in Ancient Italy, “Journal of Roman Studies" 75, 1985, p. 1-19.

Raven J.E., Plants and Plant Lore in Ancient Greece, Oxford 2000.

RiddLE J.M., Conception and Abortion from the Ancient World to the Renaissance, Cambridge, Mass.London 1992.

Riddle J.M., Dioscorides on Pharmacy and Medicine, Austin 1985.

Rocca J., Anatomy and Physiology, [in:] A Companion to Science, Technology, and Medicine in Ancient Greece and Rome, vol. I-II, ed. G.L. Irby, Malden-Oxford-Chichester 2016, p. 345-359.

Rodgers R.H., L. Iunius Moderatus Columella of Gadès (ca 40 - ca 70 CE), [in:] The Encyclopedia of Ancient Natural Scientists. The Greek Tradition and its Many Heirs, ed. P. Keyser, G.L. Irby-Massie, Milton Park-New York 2008, p. 456-457.

Romano R., Aezio Amideno, [in:] Medici bizantini. Oribasio di Pergamon. Aezio d'Amida. Alessandro di Tralle. Paolo d'Egina. Leone medico, ed. A. Garzya, R. De Lucia, A. Guardasole, A.M. IeraCi Bio, M. Lamagna, R. Romano, Torino 2006, p. 255-261.

Russell B.F., Wine, Women, and the Polis: Gender and the Formation of the City-state in Archaic Rome, "Greece \& Rome" 50, 2003, p. 77-84.

Rzeźnicka Z., Kilka słów o mleku i jego przetworach, [in:] Z. Rzeźnicka, M. Koкоszко, Dietetyka

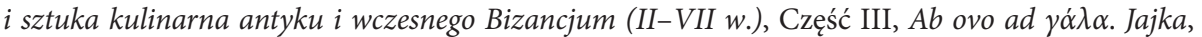
mleko i produkty mleczne w medycynie $i$ w sztuce kulinarnej (I-VII w.), Łódź 2016 [= Byzantina Lodziensia, 28].

Rzeźnicka Z., Milk and Dairy Products in Ancient Dietetics and Cuisine according to Galen's De alimentorum facultatibus and Selected Early Byzantine Medical Ttreatises, [in:] Latte e latticini. Aspetti della produzione e del consume nella società miditerranee dell'Antichità e del Medioevo. Atti del Convegno Internazionale di Studio promosso dall'IBAM - CNR e dall'IRS - FNER nell'ambito del Progetto MenSALe Atene, 2-3 ottobre 2015, ed. I. Anagnostakis, A. Pellettieri, Lagonegro 2016, p. 49-71.

Rzeźnicka Z., Mirra w antycznej medycynie i kosmetyce na podstawie pism Dioskuridesa, [in:] Lek roślinny, vol. VI, Rośliny w lecznictwie, $w$ środowisku naturalnym i w krajobrazie kulturowym, ed. B. PŁonka-Syroka, A. Syroka, Wrocław 2017, p. 53-65.

Scarborough J., Aetios of Amida (500-550 CE), [in:] The Encyclopedia of Ancient Natural Scientists. The Greek Tradition and its Many Heirs, ed. P. Keyser, G.L. Irby-Massie, Milton Park-New York 2008, p. 38-39.

Scarborough J., Asklēpiadès of Bithunia (in Rome, ca 120-90 BCE), [in:] The Encyclopedia of Ancient Natural Scientists. The Greek Tradition and its Many Heirs, ed. P. Keyser, G.L. Irby-Massie, Milton Park-New York 2008, p. 170-171. 
Scarborough J., Diodotos (Pharm.) (10-30 CE), [in:] The Encyclopedia of Ancient Natural Scientists. The Greek Tradition and its Many Heirs, ed. P. Keyser, G.L. Irby-Massie, Milton Park-New York 2008, p. 250-251.

Scarborough J., Dioskouridès of Anazarbos (ca 40-80 CE), [in:] The Encyclopedia of Ancient Natural Scientists. The Greek Tradition and its Many Heirs, ed. P. Keyser, G.L. Irby-Massie, Milton Park-New York 2008, p. 271-273.

Scarborough J., Iulius Bassus (ca 10-40 CE), [in:] The Encyclopedia of Ancient Natural Scientists. The Greek Tradition and its Many Heirs, ed. P. Keyser, G.L. Irby-Massie, Milton Park-New York 2008, p. 451.

Scarborough J., Nikerratos (of Athens?) (10-40 CE), [in:] The Encyclopedia of Ancient Natural Scientists. The Greek Tradition and its Many Heirs, ed. P. Keyser, G.L. Irby-Massie, Milton ParkNew York 2008, p. 575-576.

Scarborough J., Petrōnios Musa (ca 10-40 CE), [in:] The Encyclopedia of Ancient Natural Scientists. The Greek Tradition and its Many Heirs, ed. P. Keyser, G.L. Irby-Massie, Milton Park-New York 2008, p. 639.

Scarborough J., Philagrios of Epeiros (300-340 CE), [in:] The Encyclopedia of Ancient Natural Scientists. The Greek Tradition and its Many Heirs, ed. P. Keyser, G.L. Irby-Massie, Milton Park-New York 2008, p. 643-644.

Scarborough J., Rufus of Ephesos (ca 70-100 CE), [in:] The Encyclopedia of Ancient Natural Scientists. The Greek Tradition and its Many Heirs, ed. P. Keyser, G.L. Irby-Massie, Milton Park-New York 2008, p. 720-721.

Scarborough J., Theodora, Aetius of Amida, and Procopius: Some Possible Connections, "Greek, Roman, and Byzantine Studies" 53, 2013, p. 742-762.

Scarborough J., Nutton V., The Preface of Dioscorides' Materia Medica: Introduction, Translation, and Commentary, "Transactions \& Studies of the College of Physicians of Philadelphia" 4, 1982, p. 187-227.

Singer C., The Incense Kingdoms of Yemen: An Outline History of the South Arabian Incense Trade, [in:] Food for the Gods. New Light on the Ancient Incense Trade, ed. D.P.S. PEAcock, D.L. WILLIAMS, Oxford 2007, p. 4-26.

SQuillace G., I balsami di Afrodite. Medici, malattie e farmaci nel mondo antico, Sansepolcro 2015.

SQuillace G., Le lacrime di Mirra. Miti e luoghi dei profumi nel mondo antico, Bologna 2015.

Stamatu M., Dioskurides, [in:] Antike medizin. Ein Lexikon, ed. K.-H. Leven, München 2005, col. 227-229.

Stamatu M., Herodot [2], [in:] Antike medizin. Ein Lexikon, ed. K.-H. Leven, München 2005, col. 405-406.

Steuer R.O., Myrrhe und Stakte, Wien 1933.

Stoк F., A. Cornelius Celsus (15-35 CE), [in:] The Encyclopedia of Ancient Natural Scientists. The Greek Tradition and its Many Heirs, ed. P. Keyser, G.L. Irby-Massie, Milton Park-New York 2008, p. 217-219.

Thibodeau P., M. Porcius Cato of Tusculum (185-149 BCE), [in:] The Encyclopedia of Ancient Natural Scientists. The Greek Tradition and its Many Heirs, ed. P. Keyser, G.L. Irby-Massie, Milton Park-New York 2008, p. 686-688.

Thurmond D.L., From Vines to Wines in Classical Rome. A Handbook of Viniculture and Oenology in Rome and the Roman West, Leiden-Boston 2017. 
Tindel R.D., Zafar: Archaeology in the Land of Frankincense and Myrrh, "Archaeology" 37, 1984, p. $40-45$.

Totelin L.M.V., Hippocratic Recipes. Oral and Written Transmission of Pharmacological Knowledge in Fifth- and Fourth-century Greece, Leiden 2009.

Touwaide A., Antullos (100-260 CE), [in:] The Encyclopedia of Ancient Natural Scientists. The Greek Tradition and its Many Heirs, ed. P. Keyser, G.L. Irby-Massie, Milton Park-New York 2008, p. 101-102.

Touwaide A., Hērodotos (Pneum., of Tarsos?) (70-100 CE), [in:] The Encyclopedia of Ancient Natural Scientists. The Greek Tradition and its Many Heirs, ed. P. Keyser, G.L. Irby-Massie, Milton Park-New York 2008, p. 383-384.

TouzÉ R., Les matières perfumières employées dans la confection des hulles, onguents et pouderes parfumée en Grèce ancienne, [in:] Parfums et odeurs dans l'antiquité, ed. L. Bodiou, D. Frère, V. MehL, Rennes 2009, p. 45-59.

VIllard L., Tant de vin pour soigner les femmes, [in:] Aspetti della terapia nel Corpus Hippocraticum. Atti del IX Colloque international hippocratique (Pisa, 25-29 settembre 1996), ed. I. Garofalo, A. Lami, D. Manetti, A. Roselli, Firenze 1999, p. 219-234.

Villard L., Le vin et les femmes: un text méconnu de la collection hippocratique, "Revue des études grecques" 110, 1997, p. 362-380.

Virgili P., Culto della belleza e della seduzione, [in:] Bellezza e seduzione nella Roma imperiale, Roma, Palazzo dei Conservatori 11 giugno - 31 luglio 1990, Roma 1990, p. 19-62.

Wellmann M., Dioskurides 12, [in:] Paulys Real-Encyclopädie der classischen Altertumswissenschaft, vol. V, Stuttgart 1905, col. 1131-1142.

Wellmann M., Sextius Niger, eine Quellenuntersuchung zu Dioscorides, “Hermes” 24, 1889, p. 530-569.

WĘCOWsкi M., Sympozjon czyli wspólne picie. Początki greckiej biesiady arystokratycznej (IX-VII wiek p.n.e.), Warszawa 2011.

Wilkins J.M., Hippokratic Corpus, Regimen (ca 430-370 BCE), [in:] The Encyclopedia of Ancient Natural Scientists. The Greek Tradition and its Many Heirs, ed. P. Keyser, G.L. Irby-Massie, Milton Park-New York 2008, p. 416-417.

Younger J.G., Sex in the Ancient World from A to Z, London-New York 2005.

\begin{abstract}
The present study has resulted from a close reading of prescriptions for therapeutic wines inserted in book V of De materia medica by Pedanius Dioscorides, the eminent expert in materia medica of the $1^{\text {st }}$ century A.D.

The authors emphasise the role of wine varieties and selected flavourings (and especially of myrrh) in order to determine the social status of those to whom the formulas were addressed. This perspective gives the researchers ample opportunity for elaborating not only on the significance of wine in medical procedures but also for underscoring the importance of a number of aromatics in pharmacopoeia of antiquity and Byzantium.

The analysis of seven selected formulas turns out to provide a fairly in-depth insight into Mediterranean society over a prolonged period of time, and leads the authors to draw the following conclusions. First, they suggest that medical doctors were social-inequality-conscious and that Dioscorides and his followers felt the obligation to treat both the poor and the rich. Second, they prove physicians' expertise in materia medica, exemplifying how they were capable of adjusting market value
\end{abstract}


of components used in their prescriptions to financial capacities of the patients. Third, the researchers circumstantiate the place of medical knowledge in ancient, and later on in Byzantine society. Last but not least, they demonstrate that medical treatises are an important source of knowledge, and therefore should be more often made use of by historians dealing with economic and social history of antiquity and Byzantium.

Keywords: history of medicine, history of medical literature in antiquity and Byzantium, ancient medicine, Byzantine medicine, history of wine, wine in ancient and Byzantine medicine, myrrh in ancient and Byzantine medicine, hellebore in ancient and Byzantine medicine, women in antiquity, abortifacient wines, abortifacient medicaments, Dioscorides, Sextius Niger, Pliny the Elder.

Zofia Rzeźnicka

University of Łódź

The Waldemar Ceran Research Centre for the History and Culture of the Mediterranean Area and South-East Europe Ceraneum ul. Matejki 32/38, room 319 90-237 Łódź, Poland zosia_pwp.historyk@wp.pl

Maciej Kokoszko

University of Łódź Faculty of Philosophy and History Department of Byzantine History ul. Kamińskiego 27a 90-219 Łódź, Poland mkokoszko@komanador.pl 